\title{
THE FORGOTTEN CONSTITUTIONAL LAW OF TREASON AND THE ENEMY COMBATANT PROBLEM
}

\author{
CARLTON F.W. LARSON ${ }^{\dagger}$
}

This Article argues that the issue of enemy combatant detentions should be studied through the lens of the Treason Clause of Article III. Specifically, the Article argues that the Treason Clause prohibits the exercise of military authority over individuals who are subject to the law of treason, a category that includes not only United States citizens, but almost all persons merely present within the United States. From at least the seventeenth century through the nineteenth century, English and American treatise writers, public officials, and courts consistently distinguished between persons subject to the law of treason, and thus entitled to trial under the ordinary processes of the criminal courts, and persons who could be treated as enemies under military authority. This long-standing rule was abandoned without coherent explanation by the Supreme Court in the 1942 decision of Ex parte Quirin, a decision unfortunately affirmed in 2004 by Hamdi v. Rumsfeld. This Article argues for reinstatement of the traditional rule.

The Article also argues that many terrorist actions are appropriately punished as treason, either as acts of levying war against the United States or of adhering to their enemies. Rather than representing a fundamental departure from the ordinary criminal law paradigm, terrorist actions fit comfortably within it.

\section{INTRODUCTION}

For the past four years, legal experts have been debating constitutional issues surrounding the Bush Administration's so-called "war on terror." Although the details often vary greatly, two broad positions have emerged, which, for lack of better terms, can be labeled the "liberal" and the "conservative" positions. The "liberal" position roughly holds that the "war on terror" is not a true war in any meaningful in-

\footnotetext{
${ }^{\dagger}$ Acting Professor of Law, University of California, Davis. Special thanks to Larry Guthrie and Peg Durkin for tireless efforts in tracking down obscure sources, and to the Historical Society of Pennsylvania for permission to quote from its manuscript collection. Chiayu Chang provided valuable research assistance. This Article has benefited from the comments of Anne Joseph and participants at law faculty workshops at the University of Minnesota, UC-Davis, William \& Mary, Loyola Law School, the University of Tulsa, and Whittier Law School.
} 
ternational law sense; that only nations, not shadowy private organizations such as Al Qaeda, can ever be at "war" with the United States; that terrorism is best viewed as a large-scale problem of ordinary criminality; and that the detention of terrorist suspects as "enemy combatants" cannot be justified outside the context of a true war. ${ }^{1}$ The "conservative" position, by contrast, contends that the terrorist attacks of September 11, 2001, were genuine acts of war; that full-scale military response is appropriate; that terrorists are the soldiers of a large, well-disciplined enemy that will stop at nothing to destroy the United States and our way of life; and that such persons may be held indefinitely as enemy combatants or subjected to trial by military tribunals. $^{2}$

\footnotetext{
${ }^{1}$ See, e.g., Wayne McCormack, Military Detention and the Judiciary: Al Oaeda, the KKK and Supra-State Law, 5 SAN DIEGO INT'L L.J. 7, 71 (2004) ("Until the international community defines terrorist crimes as being violations of the 'law of war,' the U.S. system should commit that these persons be tried in civilian courts rather than by military commissions . . . because there is no coherent distinction between the alleged terrorist and the ordinary street criminal."); Jordan J. Paust, Post-9/11 Overreaction and Fallacies Regarding War and Defense, Guantanamo, the Status of Persons, Treatment, Judicial Review of Detention, and Due Process in Military Commissions, 79 Notre DAME L. ReV. 1335, 1342 (2004) ("[A]ny conflict between the United States and al Qaeda as such cannot amount to war or trigger application of the laws of war."); Kenneth Roth, The Law of War in the War on Terror, FOREIGN AFF., Jan.-Feb. 2004, at 2, 7 ("War rules should be used in [cases away from the traditional battlefield] only when no law-enforcement system exists, ... not when the rule of law happens to produce inconvenient results."); Stacie D. Gorman, Comment, In the Wake of Tragedy: The Citizens Cry Out for War, But Can the United States Legally Declare War on Terrorism?, 21 PENN ST. INT'L L. REV. 669, 674-78 (2003) (contending that the United States cannot legally declare war on terrorists); Nickolas A. Kacprowski, Note, Stacking the Deck Against Suspected Terrorists: The Dwindling Procedural Limits on the Government's Power To Indefinitely Detain United States Citizens as Enemy Combatants, 26 SEATTLE U. L. REV. 651, 669-75 (2003) (noting with alarm the then-current court decisions affirming the authority of the President to designate captured terrorists as enemy combatants).

${ }^{2}$ See, e.g., Thomas L. Hemingway, In Defense of Military Commissions, 35 U. MEM. L. REV. 1, 2 (2004) ("In short, [the conflict with Al Qaeda] is a real, not a metaphorical, war. The criminal paradigm ... is thus inapplicable.”); Derek Jinks, September 11 and the Laws of War, 28 YALE J. INT'L L. 1, 38 (2003) (“[T] he September 11 attacks constituted the initiation of an 'armed conflict' within the meaning of . . the Geneva Conventions.”); John C. Yoo \& James C. Ho, The Status of Terrorists, 44 VA. J. INT'L L. 207, 211 (2003) ("As a matter of domestic law, the President's finding [that the September 11 attacks placed the United States in a state of armed conflict] settles the question whether the United States is at war."); John C. Yoo, War and the Constitutional Text, 69 U. CHI. L. REV. 1639, 1683-84 (2002) (rejecting the contention that the use of military force requires congressional approval on the grounds that such an approach is too inflexible and unwieldy to effectively counter threats to national security). For an argument that binary distinctions between war and peace are no longer tenable, see Rosa Ehrenreich Brooks, War Everywhere: Rights, National Security Law, and the Law of Armed Conflict in the Age of Terror, 153 U. PA. L. REV. 675, 725-29 (2004).
} 
Whatever the merits of these conflicting positions under modern international law doctrine, they are both unsatisfying as a matter of basic constitutional law. Both positions overlook a critical portion of the Constitution, a provision that has much to teach us about the enemy combatant problem and about issues related to terrorism generally. This provision is the Treason Clause of Article III:

Treason against the United States, shall consist only in levying War against them, or in adhering to their Enemies, giving them Aid and Comfort. No Person shall be convicted of Treason unless on the Testimony of two Witnesses to the same overt Act, or on Confession in Open Court.

The Congress shall have Power to declare the Punishment of Treason, but no Attainder of Treason shall work Corruption of Blood, or Forfeiture except during the Life of the Person attainted. ${ }^{3}$

The Treason Clause, by its very terms, complicates both the liberal and conservative positions. First, contrary to the liberal view that only nations may engage in war against the United States, the Treason Clause explicitly states that individuals are capable of engaging in warlike actions-i.e., "levying war"-against it. Second, contrary to the conservative view that persons who engage in such warlike actions against the United States are subject to military authority, the Treason Clause again states exactly the opposite: persons who levy war against the United States are entitled to specific procedural protections, and they must be prosecuted in an Article III court with the prosecution bearing the burden of proof of an overt act by at least two witnesses.

The Treason Clause is one of the great forgotten clauses of the Constitution, and many well-trained lawyers might be surprised to learn that it even exists. Law school courses in constitutional law and criminal law ignore the subject entirely. As George Fletcher lamented over twenty years ago, "[t]he basic criminal law course focuses on homicide, sometimes on rape and burglary, but no one discusses treason." Despite occasional flurries of public interest in the subject, including the furor over the capture of John Walker Lindh in Afghanistan, ${ }^{5}$ legal scholarship on issues relating to treason is basically

\footnotetext{
${ }^{3}$ U.S. CONST. art. III, $\S 3$.

${ }^{4}$ George P. Fletcher, The Case for Treason, 41 MD. L. REV. 193, 194 (1982).

${ }^{5}$ Although many Americans clamored for a treason charge against Lindh, see, e.g., Henry Mark Holzer, Why Not Call It Treason?: From Korea to Afghanistan, 29 S.U. L. REv. 181, 221-22 (2002) (stating that the government's failure to indict Walker for treason was a "colossal mistake" because it failed to confront Walker "with the prospect of death, as a consequence of betraying [his] country and its people"), the Justice Department instead charged Lindh with, inter alia, providing material support to a ter-
} 
moribund. Apart from the seminal work of James Willard Hurst many decades ago, ${ }^{6}$ there is virtually no scholarship engaging doctrinal issues in American treason law. ${ }^{7}$ No one, it appears, has accepted

rorist organization, see Indictment at 10, United States v. Lindh, 212 F. Supp. 2d 541 (E.D. Va. 2002) (No. CR-02-37A). For an argument that Lindh did not commit treason, see Suzanne Kelly Babb, Note, Fear and Loathing in America: Application of Treason Law in Times of National Crisis and the Case of John Walker Lindh, 54 HASTINGS L.J. 1721 (2003).

${ }^{6}$ James Willard Hurst, The LaW of Treason in the United States (1971) (collecting Professor Hurst's various law review articles on the subject).

${ }^{7}$ There are several historical overviews. See, e.g., Hayes McKinney, Treason Under the Constitution of the United States, 12 ILL. L. REV. 381, 381 (1918) (showing "the distinction between the sort of language which may be used without risk of legal punishment and that other sort which may bring one into the shadow of the gallows"); Thomas P. Slaughter, "The King of Crimes": Early American Treason Law, 1787-1860, in LAUNCHING THE "EXTENDED RePublic": The Federalist ERA 54 (Ronald Hoffman \& Peter J. Albert eds., 1996) (analyzing the English origins of American treason law); Richard Z. Steinhaus, Treason, A Brief History with Some Modern Applications, 22 BroOK. L. REv. 254 (1956) (discussing the rare instances of treason prosecution in American history). There are several pieces commenting on particular trials, see, e.g., Eric L. Muller, Betrayal on Trial: Japanese-American "Treason" in World War II, 82 N.C. L. REV. 1759 (2004) (revisiting the 1944 treason trial of three Japanese American sisters); William Rehnquist, Civil Liberty and the Civil War: The Indianapolis Treason Trials, 72 IND. L.J. 927 (1997) (examining Ex parte Milligan, 71 U.S. (4 Wall.) 2 (1866)); Arthur Wakeling, The Trial of Leisler for High Treason, 23 GREEN BAG 287 (1911) (recounting the 1691 treason trial of Jacob Leisler); Wiley M. Craft, Note, Comment on Treason Trial of One Possessing Dual Nationality, 5 S.C. L.Q. 75 (1952) (discussing Kawakita v. United States, 343 U.S. 717 (1952)), on particular aspects of treason law, see, e.g., Jabez W. Loane, IV, Treason and Aiding the Enemy, 30 MIL. L. REV. 43 (1965) (exploring the parallel development of the criminal offense of treason and the military offense of aiding the enemy); Charles Warren, What Is Giving Aid and Comfort to the Enemy?, 27 YALE L.J. 331 (1918) (reviewing the acts that may constitute treason by "giving aid and comfort"); James G. Wilson, Chaining the Leviathan: The Unconstitutionality of Executing Those Convicted of Treason, 45 U. PITT. L. REV. 99 (1983) (arguing that the Eighth Amendment forbids the execution of traitors); Robert D. Powers, Jr., Comment, Treason by Domiciled Aliens, 17 MIL. L. REV. 123 (1962) (analyzing the applicability of treason law to aliens domiciled within the United States), and on procedural issues, see, e.g., Lester B. Orfield, Procedure in Treason Cases, 20 S.C. L. REv. 243 (1968) (reviewing the constitutional safeguards required in a trial for treason). Other pieces have sought to use treason law to illuminate other areas of the law. See, e.g., Stuart E. Abrams, Threats to the President and the Constitutionality of Constructive Treason, 12 COLUM. J.L. \& SOC. ProbS. 351, 389 (1976) (arguing that federal law "is unconstitutional to the extent that it [operates] to punish people solely for intending to kill the President and for manifesting that intent by verbal or written words alone"); Taylor Flynn, Of Communism, Treason, and Addiction: An Evaluation of Novel Challenges to the Military's Anti-Gay Policy, 80 IOWA L. REv. 979, 1030-43 (1995) (discussing attempts to use the Treason Clause to challenge the military's “Don't Ask, Don't Tell” policy); Monika Jain, Comment, Mitigating the Dangers of Capital Convictions Based on Eyewitness Testimony Through Treason's Two-Witness Rule, $91 \mathrm{~J}$. CRIM. L. \& CRIMINOLOGY 761, 763 (2001) (arguing that the Treason Clause's twowitness requirement should be adopted in all capital cases where eyewitness testimony is offered). A book-length treatment of early American treason law is provided in 
George Fletcher's argument that treason should be moved "to the center of our thinking about criminal law" lest we run the risk of "distorting the criminal law by overemphasizing violent crimes against persons." It might be thought that the Treason Clause is a victim of its own success; that is, like Article II's requirement that the President be at least thirty-five years old, the clause is a model of clarity-little needs to be said other than restating its basic provisions, which speak perfectly well for themselves. Yet as the United States Supreme Court explained in one of only a handful of treason cases decided by the High Court, the clause's "superficial appearance of clarity and simplicity ... proves illusory when it is put to practical application. There are few subjects on which the temptation to utter abstract interpretive generalizations is greater or on which they are more to be distrusted. The little clause is packed with controversy and difficulty." ${ }^{9}$

This Article seeks to place the Treason Clause at the heart of our thinking about the constitutional issues raised by the "war on terror," with particular emphasis on the "enemy combatant" issue. Under the constitutional law of treason, any person who is potentially subject to an American treason prosecution must be tried in a civilian court and may not be detained by the military as an enemy combatant or subjected to military tribunals.

This rule is all but forgotten today, but was once familiar to any informed lawyer in the Anglo-American world. From at least the seventeenth through the nineteenth centuries, English and American treatise writers, public officials, and courts consistently distinguished between persons subject to the law of treason and persons subject to military authority. ${ }^{10}$ Those persons subject to the law of treason were entitled to trial under the ordinary processes of the criminal courts; by contrast, those persons not subject to the law of treason could be treated as enemies and subjected to military authority. The line was explicitly drawn on the basis of allegiance: those persons who owed allegiance were subject to trial for treason; those who did not were subject to military authority. Significantly, Anglo-American law has never held that allegiance is simply a question of citizenship. Indeed, under American law, allegiance is owed to the United States by any person present within its borders other than those persons accompa-

Bradley Chapin, The American LaW of Treason: Revolutionary \& EARly NaTIONAL ORIGINS (1964).

${ }^{8}$ Fletcher, supra note 4, at 194.

${ }^{9}$ Cramer v. United States, 325 U.S. 1, $46-47$ (1945).

${ }^{10}$ See infra Part II. 
nying an invading military force. Because of the broad sweep of the doctrine of allegiance, most suspected terrorists apprehended within the United States, regardless of citizenship status, owe allegiance to the United States and may commit treason against it. It follows that such individuals cannot constitutionally be subject to military authority as enemy combatants.

This key distinction between civil and military authority, which lay at the heart of Anglo-American treason law, regrettably did not survive World War II. In Ex parte Quirin, the Supreme Court approved the trial and execution by military authorities of a man who claimed American citizenship, who had aided Nazi Germany, and who was captured in the United States. ${ }^{11}$ This precedent is flatly inconsistent with the Treason Clause, which prohibits the government from subjecting to military authority an individual otherwise subject to prosecution for treason. The Supreme Court affirmed this unfortunate error in Hamdi v. Rumsfeld, in which the Court considered the case of an American citizen captured while allegedly fighting for Taliban troops in Afghanistan and subsequently detained in the United States under military authority as an "enemy combatant."12 Although the Court quite properly rejected the government's extreme position that it could hold Mr. Hamdi indefinitely, without access to a lawyer, and without an opportunity to contest the factual basis for his detention, ${ }^{13}$ it repeated the Quirin error by holding that Hamdi was nonetheless subject to military authority. ${ }^{14}$ Only Justices Scalia and Stevens correctly recognized that, absent the suspension of habeas corpus, Hamdi was entitled to trial by an Article III court, with all of its corresponding procedural protections. $^{15}$

This Article can be seen as an extended historical concurrence to Justice Scalia's opinion in Hamdi, one which fleshes out the full dimensions of the forgotten constitutional law of treason. This law, in fact, provides significantly more protection to individuals than Justice Scalia recognizes. ${ }^{16}$ I begin in Part I with a brief historical background to the Constitution's Treason Clause, setting it in the broader context

\footnotetext{
${ }^{11} 317$ U.S. 1, 20, 31 (1942).

${ }^{12} 542$ U.S. 507, 510 (2004).

${ }^{13} I d$. at 518 .

${ }^{14} I d$. at 518-20.

${ }^{15}$ Id. at 554 (Scalia, J., dissenting) ("Where the Government accuses a citizen of waging war against it, our constitutional tradition has been to prosecute him in federal court for treason or some other crime.").

${ }^{16}$ Justice Scalia's limitation of his reasoning to United States citizens, e.g., id. at 576 , is not consistent with the constitutional law of treason, see infra Part II.
} 
of Anglo-American legal history. In Part II, I examine the related questions of allegiance and jurisdiction that lie at the heart of the Treason Clause's limitation of military authority. I conclude that, until the Quirin error, treason law consistently distinguished between those persons who owed allegiance to the United States, who were subject to the civilian law of treason, and those who did not, who were subject to military authority. Moreover, American law defines allegiance broadly, such that American citizens anywhere in the world owe allegiance to the United States, while persons merely present within the United States, other than those in the company of an invading military force, owe temporary allegiance.

The final two Parts turn to the related question of whether terrorist actions fit within the traditional scope of treason law. Although I believe the question of allegiance is itself dispositive of military jurisdiction, I nonetheless argue here that many acts of terrorism can be punished as treason. In Part III, I argue that at least some terrorist acts, such as flying a commercial airplane into the Pentagon, are acts of "levying war" against the United States. In Part IV, I argue that a terrorist organization such as $\mathrm{Al}$ Qaeda may constitute an "enemy" within the meaning of the Treason Clause, rendering any assistance by an American to Al Qaeda treasonous. Parts III and IV emphasize that terrorist actions are not so unique and so distinctively warlike as to warrant removal from the ordinary criminal justice system.

\section{THE HISTORICAL BACKGROUND TO THE TREASON CLAUSE}

\section{A. The English Background}

No provision of the Constitution is as rooted in English legal history as the Treason Clause. It would likely surprise most Americans to learn that a portion of the United States Constitution is taken almost verbatim from an English statute enacted when Geoffrey Chaucer was eight years old. The phrases "levying war" and "adhering to their enemies, giving them aid and comfort" in the Treason Clause come directly from the treason statute of 25 Edward III, enacted in $1351 .{ }^{17}$ The statute limited treason to seven basic categories: (1) compassing or imagining the death of the king, the queen, or their eldest son and heir; (2) violating the wife of the king or the wife of the king's eldest son; (3) levying war against the king in his realm; (4) adhering to the

${ }^{17}$ Treason Act, 1351, 25 Edw. 3, stat. 5, c. 2. 
king's enemies in his realm, giving them aid and comfort in the realm or elsewhere; (5) counterfeiting; (6) killing the chancellor, the treasurer, or the king's justices; and (7) the murder of a master by a servant, a husband by a wife, or a prelate by a cleric. ${ }^{18}$ The last category was generally denominated "petty treason" to distinguish it from the other categories, which constituted "high treason." This statute effectively ended the common law of treason in England. In the early seventeenth century, Sir Edward Coke wrote that the Parliament that enacted the statute "was called Benedictum Parliamentum, as it well deserved." As Coke explained, "[f] or except it be Magna Carta, no other Act of Parliament has had more honour given unto it by the King, Lords Spiritual and temporal, and the Commons of the Realm ... than this Act concerning treason has had." ${ }^{20}$ The history of English treason law is a series of variations on the themes laid down in this statute, which remains in force in England today.

\section{B. Treason Law in America}

By the time that colonial Americans began their successful treason against the King of Great Britain, English courts and commentators had spent over four hundred years parsing the words of the medieval treason statute. English treason trials had often involved acts of high daring and intrigue, from noblemen raising the standard of revolt and attempting to seize the throne to Guy Fawkes and his co-conspirators plotting to blow up the Palace of Westminster at the opening of Parliament. ${ }^{21}$ Although treason defendants came from all classes of society, many were among the most powerful people in the realm. During the English Revolution, even the King himself was tried, convicted, and executed for treason. ${ }^{22}$

Like their English counterparts, colonial Americans revered the treason statute of 25 Edward III. A widely circulated treatise, English

${ }^{18} I d$.

19 EDWARD COKE, THE THIRD PART OF THE INSTITUTES OF THE LAWS OF ENGLAND 2 (London, 5th ed. 1671) (italics added). In quotations from older sources, I have modernized spelling, capitalization, and punctuation when such modification can aid clarity without compromising meaning.

${ }^{20} \mathrm{Id}$.

${ }^{21}$ On Guy Fawkes and the Gunpowder Plot, see ANTONIA Fraser, FAITH AND Treason: THE STORY OF THE GUNPOWDER Plot (1996).

${ }^{22}$ For an insightful analysis of treason trials during the English Revolution, including the trial of Charles I, see D. AlAN ORR, TREASON AND THE STATE: LAW, POLITICS, AND IDEOLOGY IN THE ENGLISH CIVIL WAR (2002). 
Liberties, or the Free-born Subject's Inheritance, ranked the treason statute alongside the Magna Carta and the Habeas Corpus Act. ${ }^{23}$ With the exception of such notable prosecutions as the 1702 trial of Nicholas Bayard in New York, ${ }^{24}$ however, actual treason trials in America were rare. In Pennsylvania, for example, only one person, a counterfeiter named Edward Hunt, was convicted of treason prior to the American Revolution. ${ }^{25}$

With the outbreak of the Revolution, however, treason became a matter of immediate and pressing importance. In June 1776, the Continental Congress recommended that each of the colonies enact laws defining and punishing treason. The congressional resolution stated that "all persons, members of, or owing allegiance to any of the United Colonies . . . who shall levy war against any of the said colonies within the same, or be adherent to the king of Great Britain ... giving to him . . . aid and comfort, are guilty of treason against such colony." ${ }^{26}$ The colonies responded by enacting legislation that generally tracked the language of the congressional resolution.

The most noteworthy aspect of both the congressional resolution and the state treason statutes that followed it is the abolition of treason by compassing or imagining the death of the king. There was no longer a king in America, of course, but the crime might easily have been adapted to apply, for example, to state governors, the president of the Continental Congress, or the commander of the Continental Army. No such notion was ever broached, however, and the crime of compassing or imagining the king's death disappeared entirely from American law. ${ }^{27}$ The states also uniformly changed the punishment for treason from the grisly English disembowelment procedure ${ }^{28}$ to simple death by hanging. ${ }^{29}$

${ }^{23}$ HENRY CARE, ENGLISH LIBERTIES, OR THE FREE-BORN SUBJECT'S INHERITANCE 62 (W.N. ed., Boston, 5th ed. 1721).

${ }^{24}$ Trial of Colonel Bayard, (1702) 14 Howell's St. Trials 471 (Honourable Council) (N.Y.).

253 Minutes of the Provincial Council of Pennsylvania 109-10 (Phila., Jo. Severns \& Co. 1852).

${ }^{26} 5$ JOURnAls OF THE CONTINENTAL CONGRESS 475 (Worthington Chauncey Ford ed., 1906).

${ }^{27}$ But see State v. M'Donald, 1837 WL 631, at*4 (Ala. 1837) (holding that the English case law under the compassing clause was relevant to evaluating the intent element under an Alabama statute prohibiting the encouragement of a slave rebellion).

${ }^{28}$ As Blackstone described it:

The punishment of high treason in general is very solemn and terrible. 1 .

That the offender be drawn to the gallows, and not to be carried or walk;

though usually a sledge or hurdle is allowed, to preserve the offender from 
When the Constitutional Convention convened in 1787, treason was hardly among the most momentous of the issues confronting the delegates. Nonetheless, they viewed the crime's definition as serious enough to warrant inclusion in the Constitution itself. ${ }^{30}$ The delegates limited treason to two particular offenses: "levying war" against the United States and "adhering to their enemies, giving them aid and comfort." ${ }^{\prime 1}$ This language came directly from the statute of 25 Edward III. ${ }^{32}$ Circumstantial evidence suggests that James Wilson, who had served as defense counsel in several prominent Pennsylvania treason trials during the War for Independence, played a significant role in shaping the final contours of the Treason Clause. ${ }^{33}$ In his famous law lectures of 1790, Wilson would explain that the Constitution's definition of treason was deliberately "transcribed from a part of the statute of Edward the third" so that its language would be "recommended by the mature experience, and ascertained by the legal interpretation, of numerous revolving centuries." ${ }^{34}$ Wilson added:

This statute has been in England, except during times remarkably tyrannical or turbulent, the governing rule with regard to treasons ever since. Like a rock, strong by nature, and fortified, as successive occasions required, by the able and honest assistance of art, it has been impregnable by all the rude and boisterous assaults, which have been made upon it, at different quarters, by ministers and judges; and as an object of national security, as well as of national pride, it may well be styled the legal Gibraltar of England. ${ }^{35}$

the extreme torment of being dragged on the ground or pavement. 2. That he be hanged by the neck, and then cut down alive. 3. That his entrails be taken out, and burned, while he is yet alive. 4. That his head be cut off. 5 . That his body be divided into four parts. 6 . That his head and quarters be at the king's disposal.

4 William Blackstone, COMmEntaries *92. The mechanics of this procedure are thoroughly explored in JOHN BELLAMY, THE TUdOR LAW OF TREASON 201-20 (1979). Bellamy notes that in Tudor England, "the more demanding arts of decollation and disemboweling, which were peculiar to the crime of treason, were rarely practiced with great competence." Id. at 201.

${ }^{29}$ CHAPIN, supra note 7 , at 45.

${ }^{30}$ For an overview of the Treason Clause in the Constitutional Convention, see HURST, supra note 6, at 126-66.

${ }^{31}$ U.S. CONST. art. III, § 3 .

${ }^{32}$ Treason Act, 1351, 25 Edw. 3, stat. 5, c. 2.

33 HURST, supra note 6, at 135 .

342 James Wilson, Of Crimes, Immediately Against the Community, in THE Works OF JAMES WILSON 663, 665 (Robert Green McCloskey ed., 1967).

${ }^{35} I d$. at 664 . 
Wilson's argument that the Treason Clause must be interpreted in light of 25 Edward III was subsequently endorsed by Chief Justice John Marshall on circuit, ${ }^{36}$ by Justice Story in his famous Commentaries, ${ }^{37}$ and by the United States Supreme Court in the 1945 case of Cramer $v$. United States. $^{38}$

The delegates abandoned the remaining offenses in the English statute, however, and significantly tightened the standard of proof. Although English law had long required two witnesses and proof of an overt act, the Constitution required "two witnesses to the same overt act" in order to support a conviction. ${ }^{39}$ In the Pennsylvania ratifying convention, Wilson pointedly noted:

This punishment, and the description of this crime, are the great sources of danger and persecution, on the part of government, against the citizen. Crimes against the state! and against the officers of the state! History informs us that more wrong may be done on this subject than on any other whatsoever. ${ }^{40}$

\section{TREAson, AllegianCE, AND Military JURISDiction}

A core principle of the forgotten constitutional law of treason is the distinction between civilian and military authority. Until the twentieth century, Anglo-American law consistently recognized that persons subject to the law of treason are not subject to military authority. Under what conditions, though, is a person subject to the law of trea-

${ }^{36}$ See United States v. Burr, 25 F. Cas. 55, 159 (Marshall, Circuit Justice, C.C.D. Va. 1807) (No. 14,693) ("It is, therefore, reasonable to suppose . . that the term 'levying war' is used in that instrument in the same sense in which it was understood in England, and in this country, to have been used in the statute of the 25th of Edw. III. from which it was borrowed.").

37 See 3 Joseph Story, Commentaries on the Constitution of the United STATES $§ \S 1791,1793$ (1833) (describing the statute as "the pole star of English jurisprudence upon this subject" and noting that by adopting the language of the statute, the Constitution "recognized the well-settled interpretation of these phrases in the administration of criminal law, which has prevailed for ages").

${ }^{38} 325$ U.S. 1, 18 (1945) ("We can read this statute only as our forebears read itthrough the eyes of succeeding generations of English judges, to whom it has been the core of all decision, and of common-law commentators, to whom it has been the text.").

${ }^{39}$ U.S. CONST. art. III, $\S 3$ (emphasis added).

${ }^{40}$ The Debates in the Convention of the State of Pennsylvania, in 2 THE DEBATES in the SEveral State Conventions on the Adoption of the FEDERAL ConstituTION 415, 469 (Jonathan Elliot ed., Phila., J.B. Lippincott Co. 2d ed. 1836) (statement of James Wilson); see also THE FEDERALIST NO. 43, at 241 (James Madison) (Clinton Rossiter ed., 1961) (noting the importance of the Treason Clause as a restraint on governmental power). 
son? The Treason Clause itself is silent on this question, and it is tempting simply to assume that only American citizens may be prosecuted for treason. ${ }^{41}$ American treason law, however, consistently holds that treason is not a breach of citizenship, but a breach of allegiance. Persons other than citizens can be tried for treason in circumstances in which they can be said to owe a "local" or "temporary" allegiance to the United States. The sources that bear on this issue, however, are decidedly eclectic, and its full contours have never been subjected to significant academic scrutiny.

I begin the analysis in Section A with a review of the English treatises that interpreted the statute of 25 Edward III and which were widely cited in America both before and after the adoption of the Constitution's Treason Clause. These treatises recognize that a wide variety of noncitizens can be said to owe allegiance to the English crown. As a corollary, the treatises distinguish between persons subject to the law of treason and persons subject to military authority. Section B turns to various early American precedents, including the important decisional law prior to the drafting of the Constitution and early interpretations of the Constitution itself. Section C discusses the treason trial of John Brown, which pointedly raised the issue of treason and allegiance in the context of whether Brown could be guilty of treason against the State of Virginia, a state of which he was neither a citizen nor a resident. Section D briefly recounts the experience of the Confederate States of America dealing with the same issue under their constitution. Section E examines the 1873 Carlisle case, the Supreme Court's most extensive treatment of this subject. Finally, Section F reviews the Supreme Court's decision in Ex parte Quirin and argues that the Court fundamentally misunderstood American treason law and accordingly rendered the procedural protections of Article III a virtual nullity.

\section{A. The English Treatises}

The problem of distinguishing between those persons subject to the law of treason and those persons subject to the law of war was a familiar one to the English jurists who provided the first commentaries on English treason law. Although the statute of 25 Edward III did not by its terms make any such distinction, the commentators recognized that such a distinction was implicit in the very definition of trea-

\footnotetext{
${ }^{41}$ See, e.g., SANFORD LeVInSOn, CONSTITUTIONAL FAITH 116 (1988) (asserting that treason "can be committed only by a citizen").
} 
son itself. The earliest of these commentators was Sir Edward Coke, who explained:

[A]ll aliens that are within the realm of England, and whose sovereigns are in amity with the king of England, are within the protection of the king, and do owe a local obedience to the king ... and if they commit high treason against the king, they shall be punished as traitors; but otherwise it is of an enemy. ${ }^{42}$

Under this formulation, mere presence in the realm of England, rather than actual residence, would seem to be sufficient to create a local allegiance. Coke cited his own decision in Calvin's Case, in which Coke had explained, "[W]hen an alien that is in amity comes into England, because as long as he is within England, he is within the king's protection; therefore so long as he is here, he owes unto the king a local obedience or allegiance." 33 But if an "alien enemy come to invade... [is] taken in war," the report continues, "he cannot be indicted of treason ... for he never was in the protection of the king nor ever owed any manner of allegiance unto him, but malice and enmity, and therefore he shall be put to death by martial law." ${ }^{44}$

Writing in the early eighteenth century, William Hawkins contended in his Treatise of the Pleas of the Crown, "Also it seems clear, that the subjects of a foreign prince coming into England and living under the protection of our king, may, in respect of that local allegiance which they owe to him, be guilty of high treason." ambassador committing a treason against the king's life, may be condemned and executed here." ${ }^{46}$ By contrast, when "aliens" invade the

\footnotetext{
${ }^{42}$ COKE, supra note 19, at 4-5; see also CARE, supra note 23, at 65 (paraphrasing these lines from Coke).

${ }^{43}$ (1608) 77 Eng. Rep. 377, 383 (K.B.). The case concerned whether a citizen of Scotland could hold real property in England following the ascension of James VI of Scotland to the throne of England. Id. at 379. The court held that a Scottish citizen born after the accession of James VI to the throne of England could not be deemed an alien within England. Id. at 394. For a thorough discussion of the historical background to Calvin's Case, see Polly J. Price, Natural Law and Birthright Citizenship in Calvin's Case (1608), 9 Yale J.L. \& Human. 73 (1997). Price notes that:

Coke's report of Calvin's Case was one of the most important English common-law decisions adopted by courts in the early history of the United States. Rules of citizenship derived from Calvin's Case became the basis of the American common-law rule of birthright citizenship, a rule that was later embodied in the Fourteenth Amendment of the U.S. Constitution .... Id. at 74 (footnote omitted).

${ }^{44}$ Calvin's Case, 77 Eng. Rep. at 384.

451 William Hawkins, A Treatise of the Pleas of the Crown 35 (Savoy 1716) (italics omitted).

${ }^{46} I d$.
} 
kingdom in a "hostile manner," they "cannot be punished as traitors, but shall be dealt with by martial law." " Under Hawkins's formulation, a subject of a foreign prince could owe local allegiance regardless of whether that prince was at amity with the king of England. Moreover, Hawkins's requirement of "living under the protection of our king" suggests that mere presence within England may be insufficient to create a local allegiance.

Matthew Hale's influential The History of the Pleas of the Crown expanded on the views articulated by Coke and Hawkins. Because each subject received "protection from the king and his laws," he was accordingly "bound by his allegiance to be true and faithful to the king." "And hence it is, that if an alien enemy come into this kingdom hostilely to invade it, if he be taken, he shall be dealt with as an enemy, but not as a traitor, because he violates no trust nor allegiance." ${ }^{49}$ A different rule obtains, however, when the alien has been living within the king's realm. As Hale explained, "if an alien, the subject of a foreign prince in amity with the king live here, and enjoy the benefit of the king's protection, and commit a treason, he shall be judged and executed, as a traitor; for he owes a local allegiance. ${ }^{50}$ In the event that a war is declared between the alien's sovereign and the king of England, if "that alien continues here in England without returning to his natural sovereign, but under the cover and protection of the king of England commits a treason, he shall be judged and executed as a traitor; for by continuing here he continues the owning of his former local allegiance." ${ }^{51}$ Hale further explained that if

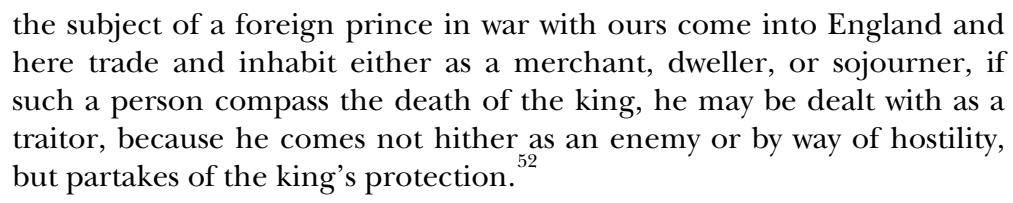

This rule rested on the broad principles of Magna Carta, under which "every foreigner living publicly and trading here [in England] is under the king's protection." ${ }^{53}$ Departing from Hawkins, Hale con-

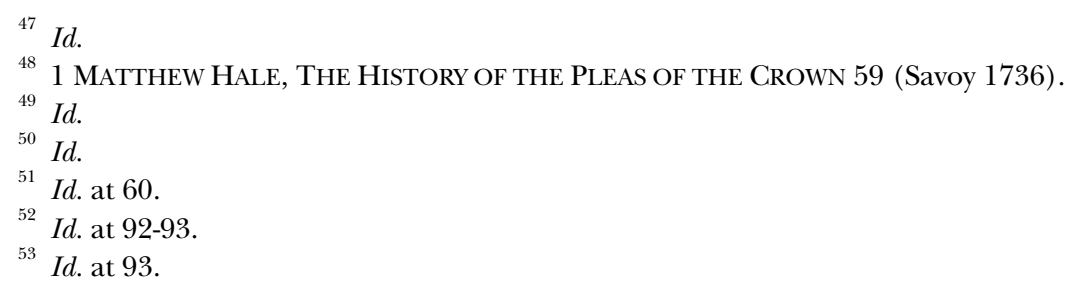


cluded that a foreign ambassador must always be dealt with "as an enemy by the law of war or nations, and not as a traitor." ${ }^{54}$

Michael Foster, writing in the middle of the eighteenth century, generally concurred with the reasoning of his predecessors, although he introduced a distinction between "local allegiance," owed by aliens whose sovereign was at amity with England, and "temporary local allegiance," owed by those whose sovereign was not. "An alien whose sovereign is in amity with the crown of England, residing here [in England] and receiving the protection of the law owes a local allegiance to the crown during the time of his residence" and may be dealt with as a traitor, since "his person and personal estate are as much under the protection of the law as the natural-born subject's and if he is injured in either, he has the same remedy at law for such injury." ${ }^{55}$ An "alien whose sovereign is at enmity with us living here under the king's protection ... may likewise be dealt with as a traitor. For he owes a temporary local allegiance, founded on that share of protection he receives." ${ }^{56}$ Foster's emphasis on residence suggests that an alien merely passing through England may not owe either form of allegiance.

William Blackstone devoted far less attention to this issue than any of his predecessors. In the first volume of his Commentaries, he stated, "Local allegiance is such as is due from an alien, or stranger born, for so long time as he continues within the king's dominion and protection: and it ceases, the instant such stranger transfers himself from this kingdom to another., ${ }^{, 57}$ In his chapter on high treason, Blackstone recalled the distinction between natural and local allegiance and explained that treason was an offense that was a "breach of this duty of allegiance, whether natural and innate, or local and acquired by residence. ${ }^{\circ 8}$

The treatise literature thus firmly supports two broad propositions. First, noncitizens residing within England owed a local allegiance to the English crown, and a breach of that allegiance by committing one of the acts enumerated in the statute of 25 Edward III was

${ }^{54}$ Id. at 96.

55 Michael Foster, A Report of SOME ProceEdings ON THE COMMission OF OYER AND TERMINER AND GOAL DELIVERY FOR THE TRIAL OF THE REBELS IN THE YEAR 1746 In THE COUNTy OF Surry, AND of OTHER Crown CASES, TO Which ARE AdDED Discourses UPON A FEW BRANCHES OF THE CROWN LAW 185 (Oxford, Clarendon Press 1762).

${ }^{56} I d$.

${ }^{57} 1$ BLACKSTONE, supra note 28 , at $* 358$.

${ }^{58} 4$ id. at $* 74$. 
treason appropriately punished by the civil courts, not by the military. Second, alien enemies captured as part of an invading force are not subject to the law of treason but instead are subject to military authority. In short, there was a fundamental distinction, rooted in allegiance, between those persons subject to civilian authority and those persons subject to military authority with respect to crimes against the state. These propositions are so firmly established that they can be said to be part of the general English law of treason with which the Framers and ratifiers of the United States Constitution were familiar. ${ }^{59}$ What is somewhat less clear is whether persons merely present within the kingdom, but not in the company of a hostile invading force, owe such a local allegiance. As noted, Coke seems to suggest that mere presence is enough, whereas other authors seem implicitly to require something more.

\section{B. Early American Precedents}

\section{The Continental Congress}

The colonial period of American history does not appear to have raised the issues of temporary and local allegiance and the scope of military jurisdiction in any significant fashion. On June 24, 1776, however, the Continental Congress recommended that the individual states enact treason legislation. The resolution stated that

all persons abiding within any of the United Colonies, and deriving protection from the laws of the same, owe allegiance to the said laws, and are members of such colony; and ... all persons passing through, visiting, or make [sic] a temporary stay in any of the said colonies, being entitled to the protection of the laws during the time of such passage, visitation, or temporary stay, owe, during the same time, allegiance thereto. ${ }^{60}$

${ }^{59}$ In the 1807 treason trial of Aaron Burr, Chief Justice Marshall stated that when interpreting the Treason Clause,

[p] rinciples laid down by such writers as Coke, Hale, Foster, and Blackstone, are not lightly to be rejected. These books are in the hands of every student. Legal opinions are formed upon them; and those opinions are afterwards carried to the bar, the bench and the legislature. In the exposition of terms, therefore, used in instruments of the present day, the definitions and dicta of those authors, if not contradicted by adjudications, and if compatible with the words of the statute, are entitled to respect.

United States v. Burr, 25 F. Cas. 55, 160 (Marshall, Circuit Justice, C.C.D. Va. 1807) (No. 14,693); see also HURST, supra note 6, at 7-8 (arguing that English legal treatises are the most useful sources for interpreting the Treason Clause).

${ }^{60} 5$ JOURNALS OF THE CONTINENTAL CONGRESS, supra note 26, at 475. 
The resolution further specified that any person who levied war against his colony or adhered to the king of Great Britain or other enemies of the colonies would be guilty of treason against the colony. ${ }^{61}$ The scope of this resolution is significant, as Congress squarely stated what had been only implicit in some of the English treatisesthat even a temporary visit to the United States imposes duties of temporary allegiance, the breach of which is treason. Many states quickly responded by enacting treason legislation that substantially tracked the language of the congressional resolution. ${ }^{62}$

Two months later, Congress resolved "that all persons not owing allegiance to America, "found lurking as spies in or about the fortifications or encampments of the armies of the United States'" would be subject to punishment by court-martial. ${ }^{63}$ Again, Congress recognized an important distinction with respect to military jurisdiction between those persons who owed allegiance to the United States and those who did not. General George Washington would later disapprove a court-martial sentence of a New Jersey man for "taking arms to the enemy." Washington stated that he was "not fully satisfied of the legality of trying an inhabitant of any state by military law, when the civil authority of that state has made provision for the punishment of persons taking arms with the enemy." ${ }^{65}$

\section{The Chapman Case}

In 1781, in Respublica v. Chapman, ${ }^{66}$ the Pennsylvania Supreme Court was squarely confronted with the issue of who could be said to owe allegiance to the State of Pennsylvania. As this is the only American decision predating the Constitution addressing this issue, it is worth considering in some detail. The defendant, Samuel Chapman, had left the State of Pennsylvania in December 1776 and joined the British army. ${ }^{67}$ On June 15, 1778, the Supreme Executive Council, the state's governing executive board, proclaimed Chapman attainted of

${ }^{61} I d$.

62 See HURST, supra note 6, at 116-17 n.35 (providing citations to laws enacted in nine states by the end of 1777).

${ }^{63}$ LOUis Fisher, Military Tribunals ANd Presidential POWER 9 (2005) (quoting 5 JOURNALS OF THE CONTINENTAL CONGRESS, supra note 26, at 693).

Id. at 10 .

${ }^{65}$ Id. (quoting 11 GEORGE WASHINGTON, THE WRITINGS OF GEORGE WASHINGTON 262 (John C. Fitzpatrick ed., 1934)).

${ }^{66} 1$ Dall. 53 (Pa. 1781).

${ }^{67}$ Id. at 53 . 
treason. $^{68}$ In 1780, Chapman was captured on board a British ship and subsequently brought to Pennsylvania. ${ }^{69}$ Pursuant to the attainder proclamation, Chapman was brought before the Pennsylvania Supreme Court to provide reasons why execution should not be rendered against him as an attainted traitor. Chapman asserted that he never owed allegiance to the State of Pennsylvania and therefore could not commit treason against it. ${ }^{70}$ In the subsequent jury trial, Chapman's attorney pointed to the chaotic interregnum that followed the collapse of royal government in Pennsylvania after independence and argued that there was no functioning government in Pennsylvania when Chapman departed. ${ }^{71}$ Since he was receiving no protection, he could owe no allegiance. $^{72}$ Moreover, when Pennsylvania's new government finally passed an act for the revival of the laws, the act stated that the laws were not in effect from May 14, 1776, to February 11, $1777 .^{73}$ The state's treason statute, passed on this later date, extended only to those people then residing in Pennsylvania. ${ }^{74}$ The state's attorney general, William Bradford, responded that throughout the period in question "a government under the authority of the people was administered by councils, committees, and conventions," and Chapman was therefore a subject of Pennsylvania in December 1776 when he joined the British army. ${ }^{75}$

This was not a new issue to the presiding judge, Chief Justice Thomas McKean. In August 1779, Pennsylvania's Supreme Executive Council had requested McKean's opinion on whether the state's treason statute extended to persons who had either departed the state prior to the Declaration of Independence or departed prior to the enactment of the statute. ${ }^{76}$ McKean replied that "treason being an offence, against government and tending to its dissolution, could not be

${ }^{68} I d$.

${ }^{69}$ Minutes of the Supreme Executive Council of Pennsylvania (June 26, 1780), in 12 Colonial Records of Pennsylvania 400 (AMS Press, Inc. 1968) (1853); Letter from Joseph Reed, President, Supreme Executive Council, to Jeremiah Powell, President, Massachusetts Bay (May 19, 1780), in 8 Pennsylvania Archives 254 (Samuel Hazard ed., Phila., Joseph Severns \& Co. 1853).

${ }^{70}$ Chapman, 1 Dall. at 53.

${ }^{71} I d$.

${ }^{72} I d$.

${ }^{73} I d$. at 54 .

${ }^{74} \mathrm{Id}$.

${ }^{75} I d$. at 54-55.

${ }^{76}$ Letter from Thomas McKean, Chief Justice, to Joseph Reed, President, Supreme Executive Council (Aug. 13, 1779), in 7 PENNSYLVANIA ARCHIVES, supra note 69, at 644. 
committed in Pennsylvania until a new government was formed." ${ }^{\text {"7 }} \mathrm{He}$ admitted that the turbulence of 1776 made it unclear exactly when the government was formed and concluded that in such an "unprecedented and doubtful" case, only those people who resided in the state on February 11, 1777, could be subject to the treason laws; those who departed earlier should be treated under military law as prisoners of war. $^{78}$

The Chief Justice drew on this advisory opinion in his charge to the jury in the Chapman case, ${ }^{79}$ but the intervening two years had resulted in a subtle transformation of his views. He now asserted that sovereignty had been lodged in Congress and in the councils and committees of safety that had taken an active role in governing the state. $^{80}$ In any event, allegiance was due to Pennsylvania at least from November 28, 1776, when Pennsylvania's new legislature convened. ${ }^{81}$ Although no treason statute had then been enacted, treason "might certainly have been committed, before the different qualities of the crime were defined, and its punishment declared by positive law." ${ }^{82}$ Chapman may therefore have been subject to the subsequently enacted treason law, but for the peculiar drafting of the January 28, 1777 , act for the revival of the laws, which seemed to imply that the common law had ceased in Pennsylvania from independence until the act itself renewed it. ${ }^{83}$ On February 11, 1777, the legislature had declared that allegiance was due only from those persons then in the state, or who should thereafter become inhabitants. ${ }^{84}$ The most sensible reading of this statute, McKean held, was that the legislature intended "to allow a choice of his party to every man," consistent with the right to choose one's own side in a civil war. ${ }^{85}$

77 Id. at 645 .

${ }^{78} \mathrm{Id}$.

${ }^{79}$ Treason cases were tried in the Pennsylvania Supreme Court itself, sitting as a Court of Oyer and Terminer. The only appeal lay to the Supreme Executive Council for clemency. JOHN M. COleman, ThOmAs MCKEAN: Forgotten LEADER OF THE REVOLUTION 223, 230, 240-41 (1975).

${ }^{80}$ Chapman, 1 Dall. at 56.

${ }^{81}$ Id. at 57.

${ }^{82} I d$.

${ }^{83} I d$. at 58

${ }^{84} I d$. at $58-59$.

${ }^{85} I d$. at 59. Historian James Kettner ties the Chapman decision to the developing idea of "volitional allegiance," that is, the idea that citizenship can be a matter of personal choice and not fixed immutably at birth. See James H. Kettner, The DevelopMENT OF AMERICAN CITIZENSHIP, 1608-1870, at 194-97 (1978) (indicating that citizenship in the years immediately after independence resulted from an act demonstrating 
McKean's two opinions suggest that he too read temporary allegiance broadly, such that it would encompass all those within the territory of a functioning government. He nonetheless tied that allegiance tightly to the existence of a government (as opposed to society or the state in general). Presumably, the absence of government results in the destruction of the reciprocal ties of protection and allegiance upon which a treason charge is ultimately predicated. ${ }^{86}$ Moreover, he recognized the important distinction between those persons subject to the law of treason and those persons subject to military authority.

\section{The United States Constitution and Subsequent Explications}

Like the statute of 25 Edward III, the Treason Clause of the United States Constitution does not, by its own terms, say anything about allegiance. Nothing in the records of the Constitutional Convention or the ratifying debates indicates that anybody gave the issue of allegiance any thought. When the First Congress convened in 1789 , however, it promptly enacted a treason statute that contained an explicit allegiance requirement, providing punishment for "any person or persons owing allegiance to the United States of America" who committed treason. ${ }^{87}$ The statute also defined misprision of treason, although, curiously, the statute did not by its terms limit this crime to those persons owing allegiance to the United States. ${ }^{88}$ In United States v. Wiltberger, Chief Justice Marshall explained that this was a distinction without a difference:

Treason is a breach of allegiance, and can be committed by him only who owes allegiance either perpetual or temporary. The words, there-

assent to be bound by the government). Issues similar to those in Chapman were raised in McIlvaine v. Coxe's Lessee, in which the United States Supreme Court held that a man who left New Jersey in 1777 remained a citizen of New Jersey and owed allegiance to it. 8 U.S. (4 Cranch) 209, 215 (1808); see also KETTNER, supra, at 199-204 (summarizing the holding and background of McIlvaine). The court based its decision largely on contemporary New Jersey legislative pronouncements to that effect. McIlvaine, 8 U.S. (4 Cranch) at 214. Arguments of counsel in McIlvaine are reported at 6 U.S. (2 Cranch) 280 (1804).

${ }^{86}$ In 1776, South Carolina Chief Justice William Henry Drayton argued in a grand jury charge that an American could not be guilty of treason against the King of Great Britain, given that the King had declared the Americans out of his protection, thereby absolving Americans' obligations of allegiance. See William Henry Drayton, A CHARGE ON THE RISE OF THE AMERICAN EMPIRE 5 (Charlestown, David Bruce 1776).

${ }^{87}$ Act of Apr. 30, 1790, ch. 9, $\S 1,1$ Stat. 112, 112 (current version at 18 U.S.C. $\S 2381(2000))$

${ }^{88} I d . \S 2$. 
fore, "owing allegiance to the United States," in the first section, are entirely surplus words, which do not in the slightest degree, affect its sense.

The construction would be precisely the same were they omitted. ${ }^{89}$

In his law lectures of 1790 , James Wilson attempted to clarify the law on who could commit treason in America. Because Wilson, former defense counsel to accused traitors during the Revolution, played such a significant role in drafting the Treason Clause of the Constitution, ${ }^{90}$ his remarks merit considerable attention. Wilson contended that English law on this subject was needlessly convoluted, and he proposed a simpler rubric: any person who owed obedience to the United States could commit treason against it. Who owed such obedience? Any person who received protection from the United States. ${ }^{91}$ Wilson explained that the term "obedience" was preferable to the term "allegiance," because "in England, allegiance is considered as due to the natural, as well as to the moral person of the king; to the man, as well as to the represented authority of the nation." ${ }^{92}$ By contrast, in America, "the authority of the nation is the sole object on one side." Wilson was evidently quite proud of this formulation, which he described as "plain and easy, as well as proper and accurate." Moreover, everyone "without the possibility of a mistake" could know whether he owed such obedience, since "[e]very one has a monitor within him, which can tell whether he feels protection from the authority of the United States; if he does, to that authority he owes obedience." ${ }^{95}$ The value of this latter assertion, which seems to add a particularly subjective element to the law, is arguable. What is clear, however, is the greater clarity that the "protection" standard brings over the older English precedents. A person openly traveling within the United States, even for only a day or two, is entitled to protection by the United States, even though that person is clearly not a citizen, and may not meet refined tests of "local allegiance." Indeed, the only persons in the United States who would not receive protection would

${ }^{89} 18$ U.S. (5 Wheat.) 76, 97 (1820). In an earlier decision, the Court had held that the crime of misprision of treason as set forth in a federal statute defining and punishing certain acts committed on the high seas was "necessarily confined to any person or persons owing permanent or temporary allegiance to the United States." United States v. Palmer, 16 U.S. (3 Wheat.) 610, 631 (1818).

${ }^{90}$ See supra note 33 and accompanying text.

${ }^{91} 2$ WILSON, supra note 34 , at 664-66.

${ }^{92} I d$. at 666 (footnote omitted).

${ }^{93} I d$.

${ }^{94} I d$.

${ }_{95} I d$. 
be those who had covertly entered for hostile purposes and who have no intention of ever invoking government aid, or those who had entered with an invading force.

In 1806, the U.S. Congress enacted legislation echoing the August 1776 resolution of the Continental Congress. ${ }^{96}$ The statute provided that, in times of war, "all persons not citizens of, or owing allegiance to the United States of America, who shall be found lurking as spies, in or about the fortifications or encampments of the armies of the United States," could be sentenced to death by court-martial. ${ }^{97}$ The limitation, again, is significant. Citizens or other persons owing allegiance simply were not subject to military authority for actions of this sort, even in time of war.

During the War of 1812, New York's highest court ruled that persons subject to the law of treason could not be subject to military authority. ${ }^{98}$ Affirming a $\$ 779.25$ damages verdict against a federal military officer for illegally detaining an American citizen, the court held:

None of the offences charged against [the detainee] were cognizable by a court-martial, except that which related to his being a spy; and if he was an American citizen, he could not be charged with such an offence. He might be amenable to the civil authority for treason; but could not be punished under martial law, as a spy. ${ }^{99}$

The court emphasized that "[i]f the defendant was justifiable in doing what he did, every citizen of the United States would, in time of war, be equally exposed to a like exercise of military power and authority."

${ }^{96}$ For a description of the August 1776 resolution, see supra note 63 and accompanying text.

${ }_{97}$ Act of Apr. 10, 1806, ch. 20, art. 101, § 2, 2 Stat. 359, 371 (emphasis added).

${ }^{98}$ Smith v. Shaw, 12 Johns. 257 (N.Y. Sup. Ct. 1815).

${ }^{99} I d$. at 265.

${ }^{100} I d$. at 266 (italics omitted). In 1867, the Illinois Supreme Court relied in part on Smith v. Shaw to uphold damages awards against federal officials for detaining an Illinois citizen for allegedly being an "active member of a disloyal secret society known as the "Knights of the Golden Circle"” and for being "deeply engaged in aiding said society in their treasonable purposes." Johnson v. Jones, 44 Ill. 142, 145, 159 (1867). The court held that the military had no authority over such individuals and noted that even during the 1790s in England, the Pitt administration "acted only through the ordinary agencies of the civil courts, and made no use of the military arm under the pretense that the offending persons were belligerents or public enemies." Id. at 160. 
court had no occasion to discuss the broader issues of temporary and local allegiance. ${ }^{101}$

During the first half of the nineteenth century, American courts made occasional pronouncements on the nature of temporary or local allegiance, although seldom in the context of treason. ${ }^{102}$ The issue of temporary and local allegiance thus fell into somnolence, until the night of October 16, 1859.

\section{The Treason Trial of John Brown}

That night, John Brown and eighteen armed men, who had been hiding out on a farm in Maryland, crossed the Potomac River over the Baltimore and Ohio Railroad bridge and seized a federal arsenal in the small town of Harper's Ferry, Virginia. ${ }^{103}$ The avowed purpose of John Brown's Raid, as it became known, was to encourage a widespread slave revolt. ${ }^{104}$ The raid, poorly planned and clumsily executed, was quickly suppressed by federal troops led by Robert E. Lee and J.E.B. Stuart. ${ }^{105}$ Although antislavery activists throughout the

${ }^{101}$ For further analysis of the case and others from the War of 1812, see Ingrid Brunk Wuerth, The President's Power To Detain "Enemy Combatants": Modern Lessons from Mr. Madison's Forgotten War, 98 Nw. U. L. REV. 1567, 1580-93 (2004).

${ }^{102}$ See, e.g., The Pizarro, 15 U.S. (2 Wheat.) 227, 246 (1817) (“[A] person domiciled in a country, and enjoying the protections of its sovereign, is deemed a subject of that country. He owes allegiance to the country, while he resides in it ...."); Charge to Grand Jury-Treason, 30 F. Cas. 1047, 1049 (C.C.E.D. Pa. 1851) (No. 18,276) ("[T]reason against the United States may be committed by any one resid[ing] or sojourning within its territory and under the protection of its laws, whether he be a citizen or alien.”); Puckett v. Pope, 3 Ala. 552, 555 (1842) (“A citizen of one State, who comes within the territory of another, contracts a temporary allegiance to it, and may be subjected to the process of its Courts, and bound personally by a judgment there rendered."); Dunham v. Lamphere, 69 Mass. (3 Gray) 268, 275 (1855) (“And surely those inhabitants of other states, who come within the territorial limits of this state, and thereby owe a temporary allegiance, and become amenable to its laws, have no just reason to complain, if . . they are bound to conform to a salutary law, necessary for the common good.”); Heridia v. Ayres, 29 Mass. (12 Pick.) 334, 345 (1832) ("[E]very stranger . . . , coming within [Massachusetts's] jurisdiction, owes a temporary allegiance and is bound by its laws."); Bissell v. Briggs, 9 Mass. (8 Tyng) 462, 470 (1813) ("[A]n inhabitant of one state may, without changing his domicile, go into another; he may there contract a debt or commit a tort; and while there he owes a temporary allegiance to that state, is bound by its laws, and is amenable to its courts."); Shumway v. Stillman, 4 Cow. 292, 296 (N.Y. Sup. Ct. 1825) (quoting Bissell).

${ }^{103}$ See OSWALD GARRISON VILLARD, JOHN BROWN: 1800-1859: A BIOGRAPHY FIFTY YEARS AFTER 426-33 (1910) (recounting the raid on Harper's Ferry).

104 James M. McPherson, The Illustrated Battle Cry of Freedom: The Civil WAR ERA 159 (2003).

${ }^{105}$ Id. at $161-62$. 
North seized on Brown as a hero, ${ }^{106}$ the South, always haunted by the specter of slave revolts, viewed Brown's actions as direct threats to the very existence of the state. ${ }^{107}$ Accordingly, Brown and several of his men were indicted for committing treason against the State of Virginia by levying war against it, as well as for murder and conspiracy. Ten days after the failed raid, Brown's trial began in nearby Charles Town, Virginia. ${ }^{108}$

Whether treason against an individual state was or is a viable crime is a fascinating question, but one that lies beyond the scope of this Article. ${ }^{109}$ What is important for present purposes is the significant issue of allegiance raised by Brown's raid. Brown was neither a citizen nor a resident of Virginia, and his arrival in Virginia exactly coincided with his alleged act of levying war. How then could he be guilty of treason against the State of Virginia? Brown's attorneys raised this argument, although they did not dwell on it at any length. As they saw it, "no man is guilty of treason, unless he be a citizen of the state or government against which the treason so alleged has been committed." Because Brown was "not bound by any allegiance to this State, [he] could not, therefore, be guilty of rebellion against it."

Virginia could be expected to counter that treason is not defined by citizenship but by allegiance, and that Brown was bound by tempo-

${ }^{106}$ Id. at $164-65$.

${ }^{107} I d$. at $163-64$

${ }^{108} I d$. at 162-63; Stephen B. OAtes, To Purge This Land with Blood: A BiogRAPHY OF JOHN BROWN 309 (1970). For a narrative account of Brown's trial, see Steven Lubet, John Brown's Trial, 52 ALA. L. REV. 425 (2001). Brown and his co-defendant suffered from various sword and bullet wounds and spent the trial reclining on a cot and a mattress, respectively, rising occasionally to make certain points and then returning to their supine positions. At one point, the case reporter notes that after the conclusion of a speech, "John Brown then lay down again, drew his blanket over him, closed his eyes and appeared to sink in tranquil slumber." The Trial of John Brown for Treason and Insurrection, in 6 AMERICAN STATE TRIALS 700, 763 (John D. Lawson ed., 1916) [hereinafter The Trial of John Brown] (emphasis omitted).

${ }^{109}$ Even if treason against a state is a viable crime, it seems doubtful that seizing a federal arsenal would qualify as a state, rather than a federal, crime. An early, largely unsympathetic biographer of Brown would write defensively in 1910:

The Federal Courts, it must be remembered, were not then as important as today; the nearest Federal prison was at some distance, and [Governor] Wise had no desire to have it said that the State of Virginia was forced to hide behind the skirts of the Federal Government, and to obtain its help to punish those who violated her soil and killed her citizens.

VILLARD, supra note 103, at 477.

110 The Trial of John Brown, supra note 108, at 782.

${ }^{111}$ Id.; see also id. at 792 ("[T] his prisoner is not a citizen of Virginia, and he therefore cannot be found guilty of treason."). 
rary or local allegiance to Virginia when he entered into its territory. Prosecuting attorney Andrew Hunter made this argument only obliquely, noting that treason could be committed by persons who are not citizens, although he did not explain why. ${ }^{112}$ He then moved into a convoluted argument involving the Privileges and Immunities Clause of the Federal Constitution. Hunter argued that Brown was in fact a citizen of Virginia, because Brown entered Virginia "with the immunities given by the Constitution" and was not "divested of the responsibilities belonging to those immunities." ${ }^{113}$ With swelling rhetoric, Hunter asked:

By the Federal Constitution, he was a citizen when he was here, and did that bond of Union-which may ultimately prove a bad bond to us in the South-allow him to come into the bosom of the Commonwealth, with the deadly purpose of applying the torch to our buildings and shedding the blood of our citizens? ${ }^{114}$

One may well doubt the geographical and anatomical perspicuity of one who would equate Harper's Ferry (on Virginia's northern border) with the "bosom" of the commonwealth, but that is the least of the oddities in this argument. The Privileges and Immunities Clause had never been construed to mean that any citizen of one state became a citizen, even temporarily, of any other state that she happened to enter. ${ }^{115}$ And indeed, Hunter appeared to recognize as much when he abruptly shifted course and rested his argument on a provision in the Virginia Code that defined a Virginia citizen to include "all those white persons born in any other State of this Union who may become residents here." ${ }^{116}$ This argument is, of course, inconsistent with the notion that anyone passing through Virginia is thereby a citizen of Virginia for the duration of her sojourn in the state. Hunter then asserted that "when this man came to Virginia and planted his feet on Harper's Ferry, he came there to reside and hold the place permanently." 117 Hunter's theory, apparently, was that violent seizure of

${ }^{112}$ Id. at 796 .

113 Id. at 797 .

${ }^{114} \mathrm{Id}$.

${ }^{115}$ The leading decision was Justice Washington's opinion on circuit in Corfield $v$. Coryell, which held that states could not deny certain fundamental rights to citizens of other states. 6 F. Cas. 546, 551-52 (Washington, Circuit Justice, C.C.E.D. Pa. 1823) (No. 3230). Nothing in Corfield suggested that a person entering another state became a "temporary citizen," for all purposes, of the state she was entering.

${ }^{116}$ The Trial of John Brown, supra note 108, at 797.

${ }^{117} I d$. 
property in the state was sufficient to establish legal residency. In addition to being a doubtful statement of Virginia's property or residency laws, this argument would seem to preclude a treason prosecution if Brown had instead intended to leave Harper's Ferry and engage in a random march through the South (as documents seized at his hideout in Maryland indicated ${ }^{118}$ ).

The court nonetheless agreed with Hunter's argument, rejecting the defendant's requested instruction that the jury could not convict of treason if Brown was not a citizen of Virginia, but of another state. ${ }^{19}$ The court said only that "the Constitution did not give rights and immunities alone, but also imposed responsibilities." ${ }^{200}$ In denying Brown's post-conviction motion for arrest of judgment, the court stated, "[W] herever allegiance is due, treason may be committed." ${ }^{121}$ The court did not explain precisely why Brown owed allegiance to Virginia.

Brown's attorneys subsequently filed an unsuccessful petition for review with the Virginia Court of Appeals. Their primary argument was that the indictment was defective because it failed to allege that Brown was a citizen of Virginia or of the United States. ${ }^{122}$ They relied heavily on Chief Justice Marshall's decision in United States v. Wiltberger and cited extensively to English authorities. ${ }^{123}$ They also argued that, on the merits, Brown owed no allegiance to Virginia, since he had entered the state "modo guerrino." "124 "[I]f he came in the manner of an enemy, so as not to entitle himself to the protection of her laws," he could not be charged with treason, "allegiance and protection being reciprocal." ${ }^{125}$

The Brown case raises important and fundamental issues of treason law. ${ }^{126}$ Two years later, a federal judge would charge a grand jury

${ }^{118}$ MCPHERSON, supra note 104, at 164.

119 The Trial of John Brown, supra note 108, at 799.

${ }^{120} I d$.

${ }^{121} I d$. at 800.

${ }^{122}$ Petition for Writ of Error, Commonwealth v. Brown (Va. 1859), reprinted in RICHMOND DAILY ENQUIRER, Nov. 21, 1859, at 1.

${ }^{123} I d$.

${ }^{124} I d$.

${ }^{125}$ Id. The Court of Appeals did not issue a written opinion. Writing in 1899, Bushrod C. Washington stated, without attribution, that the allegiance issue was "the only point the court of appeals found difficulty in deciding." Bushrod C. Washington, The Trial of John Brown, 11 GREEN BAG 164, 173 (1899).

${ }^{126}$ For a strong criticism of the court's decision, see Daniel C. Draper, Legal Phases of the Trial of John Brown, 1 W. VA. HIST. 87, 103 (1940) ("The trial of John Brown was not only the unwitting caricature of a refined constitutional conception, not only a 
in Massachusetts that "[e]very sojourner who enjoys our protection, is bound to good faith toward our government, and although an alien, he may be guilty of treason by cooperating either with rebels or foreign enemies." ${ }^{127}$ Although this is a very broad definition of local allegiance, and one which likely reflected the state of the law at the time of Brown's trial, it is not obvious that Brown would have met even that relaxed standard. He did not receive, and clearly did not want to receive, any protection whatsoever from the government of Virginia. His entire time within the state was spent in hostility towards it, as evidenced by his attempt to create a provisional government with himself as the commander-in-chief. ${ }^{128}$ In this respect, he may be seen as the classic example familiar from the English treatises of an alien who is part of an invading army and is accordingly subject to military law rather than the law of treason.

On the other hand, assuming that treason against a state is a valid crime, it is hard to see why persons from outside a state would be free to engage in an activity that is prohibited to that state's own citizens. For example, if a group of Virginians gathered with arms and marched on Richmond in attempt to overthrow the state government, that would seem to clearly constitute treason by levying war against the State of Virginia. Yet if a group of armed North Carolinians crossed over the border and marched on Richmond for the same purpose, it seems peculiar that they could not be punished for the same crime, in the same way that they would be as liable as Virginians for any other crimes they might commit while within Virginia's jurisdiction. ${ }^{129}$ As Hunter seemed instinctively to grasp, the Privileges and Immunities Clause (and other constitutional provisions as well) suggests that the precedents applicable to citizens of foreign countries have no application with respect to individual states that are bound together in a federal union. The Brown decision therefore might be read for the proposition that, with respect to the issue of treason against a state,

strained and curious application of the theory of states rights, but also the Gettysburg, the veritable Pickett's charge, of the judicial side of the conflict.").

${ }^{127}$ Charge to Grand Jury-Treason, 30 F. Cas. 1039, 1040 (D. Mass. 1861) (No. 18,273).

${ }^{128}$ See VILLARD, supra note 103, at 332-33 (describing the adoption of a constitution and the election of officers for the provisional government).

${ }^{129}$ For purposes of this hypothetical, I assume that the marchers were stopped before they harmed any persons or property, so as to avoid culpability for crimes other than treason. 
mere presence in the state is sufficient to create liability for treason. ${ }^{130}$ The decision, however, arguably has no applicability to the separate issue of aliens' allegiance to the United States, although it nonetheless represents the broad approach generally taken to questions of allegiance. $^{131}$

\section{The Confederate States of America}

When the Confederate States of America seceded from the Union, they adopted a constitution that was almost identical to the United States Constitution, including its provisions on treason. ${ }^{132}$ Although the Confederate Supreme Court never sat, ${ }^{133}$ Confederate attorneys general authored a number of formal opinions on constitutional matters. In November 1863, Confederate Attorney General Wade Keyes addressed the subject of the jurisdiction of courts-martial. Specifically, he was asked to evaluate what should be done with two groups of people: (1) "disloyal citizens of Virginia, charged with enticing soldiers to desert, and piloting them to the enemy; and, also, furnishing the enemy with information of the position and movements of [Confederate troops]"; and (2) "an organized band of men, who shoot our soldiers, and rob and murder our people, but are not Federal soldiers, nor in our Army." 134

Keyes's response rested firmly on the well-established distinction between persons subject to military authority and persons subject to trial for treason. Any such person who owed "obedience to the Government of the Confederate States ... [was] guilty of treason alone, in the first class, and in the second, of treason, murder and robbery, all

${ }^{130}$ It is conceivable that modern technology could create situations in which one could levy war against a state without ever setting foot in it. For example, a renegade group could acquire short-range missiles and launch them at a neighboring state's capitol building in an attempt to destroy the state government. In such circumstances it would be impossible to argue that the members of the group owed any sort of allegiance to the other state.

${ }^{131}$ An 1866 West Virginia decision stated, without citation to any authority, that treason against the State of West Virginia could be committed only by citizens of the state. See Ex parte Quarrier, 2 W. Va. 569, 572 (1866) ("Others may be enemies, but the citizen only may be enemy and traitor also ....").

${ }^{132}$ See David P. Currie, Through the Looking-Glass: The Confederate Constitution in Congress, 1861-1865, 90 VA. L. REV. 1257, 1266 (2004) (“[T]he Confederate Constitution ... appeared to be a carbon copy of the Constitution of the United States.").

${ }^{133}$ Id. at 1262.

${ }^{134}$ Wade Keyes, Jurisdiction of Courts Martial (Nov. 18, 1863), in The OPINIONS OF The Confederate AtTorneys General, 1861-1865, at 352, 353 (Rembert W. Patrick ed., 1950). 
of which are infamous crimes." 135 Keyes concluded, "Such persons cannot, therefore, be tried by court martial for treason, murder or robbery, but must be allowed ... 'a speedy and public trial, by an impartial jury of the State and District wherein the crime shall have been committed." "'36 By contrast, military authority would extend to persons who did not owe allegiance to the Confederacy, since they were "alien-enemies carrying on aggressive war without commission from their Government." 137 If the individuals involved were Union soldiers, they could be "tried by Court Martial in the same cases in which other prisoners of war may be tried." 138 Keyes emphasized, "The Court, on such trial, would have nothing to do with allegiance or treason."139

Although obviously of no formal legal weight in American law, Keyes's opinion is nonetheless important. It demonstrates that even the Confederate states recognized that persons subject to the law of treason, including persons actively aiding the enemy and even directly attacking Confederate troops, must be prosecuted by civilian authorities in a civilian court.

\section{E. The Carlisle Case}

In the 1873 case of Carlisle v. United States, ${ }^{140}$ the United States Supreme Court offered its most extensive discussion to date of the scope of local or temporary allegiance. The case was brought by British citizens seeking to recover the value of their cotton that had been stored on a plantation in Alabama and which had been seized by Union officers during the Civil War. The lower court had denied the claim on the ground that the claimants had been engaged in providing saltpeter to the Confederate government. ${ }^{141}$ The issue in the Supreme Court turned on whether President Johnson's 1868 general pardon and amnesty for those involved in the rebellion relieved the claimants of the consequences of their assistance to the Confederacy. ${ }^{142}$ The Court concluded that the claimants, although aliens, were clearly guilty of treason and thus within the general scope of the pardon. ${ }^{143}$

${ }^{135} I d$. at 354 .

${ }^{136}$ Id. (quoting CONFEDERATE CONST., art. 1, § 9, cl. 17).

${ }^{137} I d$. at $353-54$ (italics omitted).

${ }^{138} I d$. at 354.

${ }^{139}$ Id.

${ }^{140} 83$ U.S. (16 Wall.) 147 (1873).

${ }^{141} I d$. at 149.

${ }^{142} I d$. at 151.

${ }^{143}$ Id. at $155-56$. 
In so doing, the Court laid down a broad interpretation of local allegiance. The Court first cited a treatise on international law that stated:

The rights of sovereignty ... extend to all persons and things not privileged that are within the territory. They extend to all strangers therein, not only to those who are naturalized and to those who are domiciled therein, having taken up their abode with the intention of permanent residence, but also to those whose residence is transitory. All strangers are under the protection of the sovereign while they are within his territories, and owe a temporary allegiance in return for that protection. ${ }^{144}$

The Court observed that " $[\mathrm{t}]$ his obligation of temporary allegiance by an alien resident in a friendly country is everywhere recognized by publicists and statesmen." ${ }^{145}$ The Court cited an 1851 report by thenSecretary of State Daniel Webster to President Fillmore, in which Webster had argued that the doctrine of temporary allegiance was "the universal understanding in all civilized states, and nowhere a more established doctrine than in this country." ${ }^{146}$ Webster had further explained:

[I] ndependently of a residence with intention to continue such residence; independently of any domiciliation; independently of the taking of any oath of allegiance or of renouncing any former allegiance, it is well known that, by the public law, an alien or a stranger born, for so long a time as he continues within the dominions of a foreign government, owes obedience to the laws of that government, and may be punished for treason or other crimes as a native-born subject might be, unless his case is varied by some treaty stipulation. ${ }^{14}$

The Court finally observed that "[t]he same doctrine is stated in Hale's Pleas of the Crown, East's Crown Law, and Foster's Discourse upon High Treason, all of which are treatises of approved merit." ${ }^{148}$

The Court's reference to Hale, East, and Foster is somewhat misleading, in that it disguises the breadth of the interpretation the Court had just announced. For the first time, the Court had explicitly held, in effect, that mere presence within the United States was sufficient to

${ }^{144} I d$. at 154 (quoting RICHARD WILDMAN, 1 INSTITUTES OF INTERNATIONAL LAW 40 (London, William Benning 1849)).

${ }^{145} I d$.

${ }^{146} I d$. at 155 (quoting Report from Daniel Webster, Secretary of State, U.S., to Millard Fillmore, President, U.S. (Dec. 23, 1851), in 6 THE WORKS OF DANIEL WEBSTER 526 (Boston, Little \& Brown 1858)).

${ }^{147} I d$. (quoting Report from Daniel Webster to Millard Fillmore, supra note 146, at $526)$.

${ }^{148} I d$. (italics added) (citations omitted). 
create a temporary allegiance the violation of which could be treason. It should be noted that the Court reached this conclusion not in the context of a particular treason prosecution, but in the context of determining the breadth of a pardon. ${ }^{149}$ Nonetheless, the treason context was manifest and the Court's holding is quite clear.

One might well ask what protection British citizens in the Confederacy were receiving from the government of the United States. Indeed, shortly after Carlisle, a lower court raised precisely that point. In Green's Case, which raised similar issues, the Court of Claims queried:

[I]n the case of an alien not receiving such protection, residing in the territory of a belligerent, and under a government de facto which claimed the right and exercised the power of making laws and exacting obedience, can it be said that he owed temporary allegiance to a government practically at a distance, and which was at most a government de jure seeking to re-establish its authority by force of arms?"150

The court reluctantly concluded that it was nonetheless bound by Carlisle, although it took pains to point out that the Supreme Court in Carlisle had addressed a more general issue for which "there was not a lawyer in the world who could entertain a doubt" and had "thoroughly overlooked" the only real point at issue. ${ }^{15}$

Nonetheless, Carlisle, combined with the earlier English and American precedents involving the respective spheres of military and civil authority, establishes two propositions. First, any person present in the United States, other than in the company of an invading military force, owes at least a temporary or local allegiance to the United States and can be tried for treason against the United States for acts of levying war or adhering to enemies of the United States while present within the country. ${ }^{152}$ Second, persons who owe allegiance to the

149 Id.

1508 Ct. Cl. 412,417 (1873).

151 Id. at 419-20. The Carlisle Court did note that the aliens at issue had been domiciled in Alabama prior to the outbreak of the Civil War. 83 U.S. (16 Wall.) at 147, 155. The Court did not indicate, however, whether the result would have been different if the aliens had arrived after the commencement of hostilities. For an earlier decision emphasizing the reciprocal nature of protection and allegiance, see Cohen v. Wright, 22 Cal. 293, 325 (1863) ("The government owes the duty of protection to the people in the enjoyment of their rights, and the people owe the correlative duty of obedience and support to the Government. The one is dependent on the other.").

${ }^{152}$ Citizens, of course, owe allegiance to the United States even when in foreign countries. See, e.g., Kawakita v. United States, 343 U.S. 717, 734-35 (1952) (finding that an American citizen living in Japan during World War II continued to owe allegiance to the United States, even though he also held Japanese citizenship). By contrast, the 
United States are not subject to military authority for acts that amount to treason but must be tried in the civilian courts under the full protections of Article III. By contrast, the military has authority over those persons who do not owe allegiance to the United States.

\section{F. Ex Parte Quirin: The Supreme Court Flunks Treason Law}

The issue of temporary or local allegiance did not attract significant attention during the twentieth century, although both federal and state courts occasionally invoked it in various contexts, ${ }^{153}$ including a somewhat unusual prosecution for treason under a military commission of a Japanese citizen who assisted the Japanese in Guam during World War II. ${ }^{154}$ The decision of the greatest significance to the issues raised in this Part, however, is the Supreme Court's decision in Ex parte Quirin, ${ }^{155}$ a controversial decision that the Supreme Court plurality in Hamdi v. Rumsfeld relied on to justify military authority over an American citizen captured on a battlefield. ${ }^{156}$

The facts of Quirin can be briefly summarized. In the summer of 1942, German submarines approached the coasts of Long Island and Florida. Under cover of darkness, four men emerged from each sub-

allegiance of a person who is merely temporarily present within the United States dissipates the moment that person leaves the United States.

${ }^{153}$ See, e.g., Fletes-Mora v. Rogers, 160 F. Supp. 215, 218 (S.D. Cal. 1958) ("Our law has long recognized an alien's obligation of 'temporary allegiance' to a country while he is within its territory."); In re Kowalke's Guardianship, 46 N.W.2d 275, 282 (Minn. 1950) (stating that "all persons within the state, including aliens and strangers" while present in the state, "'are under obligations of temporary, local allegiance and are entitled to the state's protection"” (quoting In re Pratt, 18 N.W.2d 147, 152 (Minn. 1945))). An 1892 grand jury charge by the Chief Justice of Pennsylvania squarely stated: "Aliens domiciled within the state and who enjoy its protection, owe temporary allegiance to it, and are amenable for treason." The Homestead Case, 1892 WL 3637, at *6 (Pa. O. \& T. 1892).

${ }^{154}$ The facts and holdings in the case, gathered from military records, are discussed in Powers, supra note 7, at 127-29, and Recent Cases, 17 GEO. WASH. L. REv. 270, 283-85 (1948). Prior to World War II, Guam was occupied by the United States, and the defendant, although a Japanese citizen, had lived in Guam under the American-led government. When the Japanese subsequently invaded and occupied the island, the defendant provided assistance to Japan. Upon American recapture of the island, he was tried for treason by a military commission convened by the Island Commander. His principal defense was that his local allegiance to the United States was overridden by his permanent allegiance to Japan when Japan occupied Guam. The Judge Advocate General's opinion affirming the conviction rejected this argument, relying on an English decision arising under somewhat similar facts in South Africa. Powers, supra note 7 , at $128-29$.

155317 U.S. 1 (1942).

${ }^{156}$ 542 U.S. 507, 518-19 (2004). 
marine, buried their Third Reich uniforms on the beach, and donned civilian attire. The men had trained at a sabotage school in Berlin and were instructed to destroy war industries and war facilities in the United States. Although all of the men had previously lived in the United States, all but one were clearly German citizens; one, however, claimed to be a United States citizen based on the naturalization of his parents in the United States while he was in his minority. The men were quickly apprehended in New York and in Chicago, and were brought before a military tribunal to be tried for offenses against the laws of war. ${ }^{157}$

The Supreme Court denied the men's petitions for habeas corpus, concluding that they were not entitled to trial in the civilian courts and could appropriately be brought before military tribunals. ${ }^{158}$ The Court distinguished between lawful combatants, who are subject to capture as prisoners of war, and unlawful combatants, who may be tried before military tribunals for offenses against the laws of war. ${ }^{159}$ Unlawful combatants, in the Court's analysis, include "[t]he spy who secretly and without uniform passes the military lines of a belligerent in time of war ... or an enemy combatant who without uniform comes secretly through the lines for the purpose of waging war by destruction of life or property...."160 The correctness of this conclusion need not concern us here. What is significant for our purposes is the Court's treatment of the issues of citizenship and treason. The Court held:

Citizenship in the United States of an enemy belligerent does not relieve him from the consequences of a belligerency which is unlawful because in violation of the law of war. Citizens who associate themselves with the military arm of the enemy government, and with its aid, guidance and direction enter this country bent on hostile acts, are enemy

${ }^{157}$ Quirin, 317 U.S. at 20-22. For an extensive discussion of the background facts and a careful analysis of the case's reasoning, see GEORGE P. FLETCHER, ROMANTICS AT WAR 96-112 (2002). See generally LOUIS FishER, NAZI SABOtEURS On TRIAL: A Military TRIAL AND AMERICAN LAW (2003) (providing an in-depth analysis of the events leading up to the Quirin decision and the judicial process used against the defendants); Michal R. Belknap, The Supreme Court Goes to War: The Meaning and Implications of the Nazi Saboteur Case, 89 MIL. L. REV. 59, 63-67 (1980) (examining the considerations that went into choosing to prosecute the defendants before a military tribunal and criticizing the Court's decision); David J. Danelski, The Saboteurs' Case, 1996 J. SuP. CT. HIST. 61 (reviewing the capture, prosecution, and appeal of the Quirin defendants).

${ }_{158}$ Quirin, 317 U.S. at 48.

${ }^{159}$ Id. at 31 .

${ }^{160} \mathrm{Id}$. 
belligerents within the meaning of the Hague Convention and the law of war. $^{161}$

Accordingly, the Court did "not find it necessary to resolve" the issue of citizenship. ${ }^{162}$ The Court then noted that "even when committed by a citizen, the offense [of being an unlawful combatant] is distinct from the crime of treason defined in Article III, $\S 3$ of the Constitution, since the absence of uniform essential to one is irrelevant to the other." ${ }^{163}$

In reaching this conclusion, the Court fundamentally misunderstood American treason law and the protective purposes of the Treason Clause. At bottom, the Court's opinion relies on two fundamental propositions: (1) that an individual can be an enemy combatant as well as a traitor and that possible susceptibility to trial for treason in a civilian court does not preclude trial by the military, and (2) that the offense of being an unlawful combatant differs from the offense of treason due to the element of the uniform. Neither of these propositions is consistent with prior law or with a due regard for the Constitution's commitment to jury trials and to significant procedural protections for persons accused of treason.

First, the Court's holding that citizens are subject to military authority for unlawful acts of war against the United States is an exception that completely swallows the rule of the Treason Clause. The very essence of the crime of treason by aiding the enemy is doing precisely what the purported United States citizen in Quirin did: wandering around the country without a uniform aiding the enemy during time of war. Indeed, since the saboteurs did not actually harm any persons or property, treason is the only crime with which the United States citizen could have been charged in a civilian court. Such a prosecution would have been subject to the procedural protections of the Treason Clause, as well as a jury trial. Instead, by permitting designation as an enemy combatant, the Quirin Court allowed the government to remove an individual from the civilian courts, and to subject him to trial, conviction, and execution by military authorities. The Treason Clause, designed to establish a high procedural threshold be-

${ }^{161} I d$. at 37-38. The scope of this holding is not entirely clear. Would Quirin permit a military tribunal for an American citizen who served in a German army that invaded the United States? Such activity would be lawful, rather than unlawful, combat, yet the Court's broad language seems to suggest that military authority might extend to that circumstance as well.

${ }^{162} I d$. at 20 .

163 Id. at 38 . 
fore permitting execution of those persons found to be disloyal, thus vanishes entirely, and the government, acting through its military arm, becomes free to do whatever it pleases. ${ }^{164}$

Second, the Court's argument that the offense of being an unlawful combatant is different than the crime of treason, due to the element of the uniform, is beside the point. The presence or absence of a uniform is significant with respect to how persons are treated within the military system itself-that is, whether the person is held as a prisoner of war or tried for offenses against the law of war as an unlawful combatant. But the presence or absence of a uniform says nothing about whether such persons belong in the military system in the first place. In essence, the Court has simply recognized a trivial, additional element to the offense of treason, and used that element as justification for eviscerating the Treason Clause itself. For example, suppose Congress declared that any person who levies war against the United States with a gun is an enemy combatant and subject to military authority. Under the Quirin Court's analysis, this would be perfectly lawful. The element of the gun, which would be the jurisdictional hook for military authority, is irrelevant to the crime of treason; thus, levying war and levying war with a gun would be separate offenses and the Treason Clause would be inapplicable. Such a result simply cannot be correct, yet it is indistinguishable from the Court's analysis in Quirin with regard to the uniform element. Quirin effectively holds that a person levying war against the United States or adhering to its enemies without a uniform is subject to military authority. Of course, it will almost always be the case that a person committing an act of treason-levying war against the United States or adhering to its enemies-will be doing so without a uniform and accordingly might be defined as an unlawful combatant. As a result, any civilian accused of treason could be simply shunted into the military system and executed without any of the protections provided by Article III.

In short, Quirin represents a significant misunderstanding of American treason law, deviating dramatically from long-standing prin-

${ }^{164}$ Cf. Duncan v. Kahanamoku, 327 U.S. 304, 329 (1946) (Murphy, J., concurring) ("The argument [supporting military trials of civilians] is as untenable today as it was when cast in the language of the Plantagenets, the Tudors and the Stuarts. It is a rank appeal to abandon the fate of all our liberties to the reasonableness of the judgment of those who are trained primarily for war."); MARK E. NEELY, JR., THE FATE OF LIBERTY 36, 43 (1991) (noting that General Henry W. Halleck, who had written a textbook on international law prior to the Civil War, reversed verdicts for treason rendered by military commissions in Missouri on the ground that "such charges were not triable by a military commission"). 
ciples separating military and civilian jurisdiction with respect to treason. As Justice Scalia noted in Hamdi, Quirin "was not this Court's finest hour." ${ }^{165}$ To the extent that Quirin holds that persons who owe allegiance to the United States may be tried by the military as enemy combatants, it is inconsistent with prior law, at odds with fundamental principles of the Constitution, and should be overruled. ${ }^{166}$

To be clear, my argument is not that a person subject to a treason charge may not be charged with other offenses. Someone who sets fire to several major government buildings while levying war against the United States is subject to prosecution for both treason and arson, and a prosecutor could properly decide to proceed only with the arson charge. Within the civilian system, prosecutors have considerable discretion in the charging of offenses. What the government cannot do, however, is recognize an element in addition to conduct that is clearly covered by the Treason Clause, and then rely on that element as a justification for the assertion of military authority and the elimination of a trial in a civilian court. ${ }^{167}$

The Quirin Court's treatment of the seven noncitizens presents a much more difficult issue. The obvious predicate question, which the Court failed to address at all, is whether they owed temporary or local allegiance to the United States. If so, they were subject to the law of treason and could not be tried by the military. They entered the country illegally, but no authority suggests that legal or illegal presence has any bearing on the question of temporary or local allegiance. The noncitizens were not part of an invading army, and thus did not rely on that army for protection. To the extent that they ultimately spent time openly in the United States, they probably satisfy the Car-

${ }^{165}$ Hamdi v. Rumsfeld, 542 U.S. 507, 569 (2004) (Scalia, J., dissenting).

166 See also HuRST, supra note 6, at 148 ("The 'absence of uniform' . . made the defendant's conduct more dangerous simply because it enabled him to appear as what he was-one of the body of citizens. And it was citizens that the limitations of the treason clause were intended to protect.").

${ }^{167}$ The Treason Clause likely does not preclude short-term military detentions in those rare battlefield situations in which the military captures a person owing allegiance to the United States. Such detentions should be narrowly limited in time, however, and the individual should have the right to demand either a trial for treason in a civilian court or his release. But see In re Territo, 156 F.2d 142, 146-48 (9th Cir. 1946) (holding, without discussion of the Treason Clause, that the United States military could hold a United States citizen as a prisoner of war). If the individual consented to remaining in military custody as a prisoner of war, however, there would seem to be little reason not to permit this choice. 
lisle test of temporary and local allegiance. ${ }^{168}$ By contrast, if they had simply remained hidden in a basement, for example, during their entire time in the country, it is possible that they would never have received the protection necessary to support temporary or local allegiance. Similarly, if these noncitizens had been captured on the beach immediately after exiting the submarine, military jurisdiction would have been appropriate. ${ }^{169}$

It should be obvious that this line of inquiry has immediate relevance with respect to suspected Al Qaeda members within the United States. If such persons are living openly in the United States, they owe temporary or local allegiance to the United States and are subject to prosecution for treason against it. As such, the September 11 hijackers, who all lived in the United States for some period of time prior to the attacks, were subject to American treason law. By contrast, if such individuals are apprehended prior to entry into the United States, military jurisdiction may be appropriate. This of course raises the problem that potential terrorists who successfully enter the United States may receive significantly different treatment than unsuccessful entrants. Why should such persons be entitled to claim the protections of the Treason Clause?

There are several answers to this question. First, susceptibility to the law of treason is not an unmitigated good. It means that the individual can be tried, convicted, and executed for the capital crime of treason against the United States, whereas the unsuccessful entrant cannot. Second, the protections of the Treason Clause were created with the full knowledge that they would extend to persons who owed only temporary or local allegiance to the United States. Nothing in the text or history of the Treason Clause indicates that its requirements may be relaxed when the individual is not a United States citizen. Third, it is not particularly anomalous that persons merely present in the country should have some rights to which unsuccessful entrants do not. The government may not seize the property of someone within the United States without just compensation, but it

${ }^{168}$ See supra notes 145-48 and accompanying text. But see Powers, supra note 7, at 129 (arguing that spies should be subject to the law of war, not the law of treason).

${ }^{169}$ Their situation differs significantly from that of Jose Padilla, the terrorist suspect detained by United States officials at Chicago's O'Hare airport and subsequently held as an enemy combatant. Rumsfeld v. Padilla, 542 U.S. 426, 430-31 (2004). Because Padilla is a United States citizen, the question of temporary or local allegiance is irrelevant. He owes permanent allegiance to the United States, and thus military jurisdiction cannot extend to him. 
may order bombings of private property in other countries without any compensation at all.

In short, there is every reason to believe that suspected $\mathrm{Al}$ Qaeda members within the United States are subject to the American law of treason.

$$
* \quad * \quad *
$$

The foregoing analysis should be sufficient to establish that any person subject to American treason law, whether or not the alleged acts are technically treasonous, may not be subjected to military jurisdiction. Nonetheless, numerous people have argued that terrorist acts are so horrific, so distinctively military, and so unique that they should be treated differently than other crimes. The peculiar nature of terrorist acts, in other words, renders military jurisdiction particularly appropriate. The remainder of this Article will demonstrate that many terrorist acts fit quite comfortably within traditional understandings of treason law.

\section{TERRORISM AND "LEVYING WAR"}

The Treason Clause refers to "levying war against the United States." But what exactly does this mean? Are terrorist actions punishable under the Treason Clause? The answers to these questions are far from obvious. Although there have been a handful of twentiethcentury treason prosecutions for adhering to the enemy, there have been no federal treason prosecutions for levying war since the nineteenth century. ${ }^{170}$ American jurisprudence regarding treason by levying war therefore has a decidedly dated feel, which renders it difficult to make conclusions about the modern scope of the law. Nonetheless, I conclude that at least certain terrorist actions constitute treason by levying war when committed by an individual owing allegiance to the United States.

${ }^{170}$ The Supreme Court of the Philippines decided several levying-of-war cases during the American occupation in the early twentieth century. See, e.g., United States v. Lagnason, 3 PHIL. REP. 472, 482 (S.C., Mar. 28, 1904) (finding a defendant guilty of treason for leading an armed band of men whose object was to establish an independent government); United States v. De Los Reyes, 3 PHIL. REP. 349, 350 (S.C., Feb. 23, 1904) (acquitting a defendant accused of treason for levying war against the United States and the Philippine Islands by serving as a captain in an organization whose object was overthrowing the Philippine government). 


\section{A. The English and Early American Background}

By the eighteenth century, English law on the subject of levying war had developed a high degree of complexity. At its core, the crime clearly included those who "directly rebel against the king, and take up arms in order to dethrone him." ${ }^{171}$ But the crime extended even more broadly. A 1768 New York publication gave an apt summary of the scope of levying war under English treason law:

Persons raising forces for any public end or purpose, and putting them-
selves in a posture of war, by choosing leaders, and resisting constables,
or the guards, etc. is high treason: and those who make an insurrection
in order to redress a public grievance, whether it be a real or pretended
one, are said to levy war against the king, though they have no direct de-
sign against his person. Where great numbers by force endeavour to
remove certain persons from the king, or to lay violent hands on a privy
counselor, or revenge themselves against a magistrate for executing his
office; or to deliver men out of prison or reform religion or the law, to
pull down all bawdy-houses, or throw down all inclosures in general, etc.
these acts will be high treason: But where a number of men rise to re-
move a grievance to their private interest; as to pull down a particular in-
closure, etc. they are only rioters.

This excerpt captures several key points about levying war under English law. First, an insurrection aimed at a public purpose was treason, whereas an insurrection intended to accomplish some private purpose was merely a riot. ${ }^{173}$ Second, levying war against the king includes using force to accomplish certain acts that lie within the king's authority. ${ }^{174}$ As the Chief Justice of New York charged a grand jury in 1726:

${ }^{171}$ HAWKINS, supra note 45 , at 37.

${ }_{172}$ EVERY MAN His OWN LAWYER 266 (New York, Hugh Gaine 1768).

${ }^{173}$ See, e.g., 4 BLACKSTONE, supra note 28 , at *82 ("[A] tumult with a view to pull down a particular house, or lay open a particular inclosure, amounts at most to a riot ...."); COKE, supra note 19, at 9 ("[I]f three, or four, or more, do rise to burn, or pull down an inclosure ... this or the like is a riot, a rout, or an unlawful assembly, and no treason."); FOSTER, supra note 55, at 209-10 (“[T] hose assemblies so armed and arrayed, if drawn together for purposes of a private nature, were not deemed treasonable ... [but rather as] a riot only."); HALE, supra note 48, at 131 ("[A] private quarrel ... seems no levying of war against the king."); HAWKINS, supra note 45, at 37 ("[W] here a number of men rise to remove a grievance to their private interest, as to pull down a particular inclosure entrenching upon their common, etc., they are only rioters.”).

${ }^{174}$ See, e.g., COKE, supra note 19, at 9 (including "tak[ing] upon the royal authority ... against the king" within the definition of levying war); HAWKINS, supra note 45, at 37 (stating that " $[\mathrm{t}]$ hose ... [who] insolently invade [the king's] prerogative, by attempting to do that by private authority, which he by public justice ought to do ... manifestly tend[] to a downright rebellion" and a levying of war against the king); FOSTER, supra note 55, at 211 ("Insurrections ... of a public and general concern by an armed force, are in construction of law high treason, within the clause of levying war."); 
Those who make an insurrection to redress a public grievance, whether real or pretended, and of their own authority attempt, with force, to redress it, are said to levy war against the king, though they have no direct design against his person, because they insolently invade his prerogative, by attempting to do that, by private authority, which he, by public justice, ought to do. ${ }^{175}$

This theory was occasionally pushed to extremes. A decision in the late seventeenth century had found pulling down all bawdy houses an act of levying war, since closing bawdy houses was apparently a prerogative of the king. Chief Justice Hale refused to join this decision, ${ }^{176}$ and one scholar notes that "it is hard to understand why this was treason, rather than riot, unless we let our knowledge of the licentious and profligate character of Charles II, then King of England, lead us to the conclusion that it was regarded as an attack upon a royal institution." ${ }^{177}$ English law also consistently held that conspiracy to levy war was not treason; a conviction could only rest on an actual levying of war. ${ }^{178}$

\section{B. Levying War and American Law}

\section{Early Authorities}

The Treason Clause itself, of course, does not define the meaning of "levying war," and there is nothing in the debates at the Constitutional Convention shedding any light on the subject. American authorities prior and subsequent to the ratification of the Constitution

4 BLACKSTONE, supra note 28 , at $* 81$ (noting that levying war may include taking arms "not only to dethrone the king, but under pretense to reform religion, or the laws").

175 The Charge Given by the Chief Justice of the Province OF New-York to THE GRAND JuRY OF THE CiTY OF NEW-YORK 12 (New York, John Peter Zenger 1727).

${ }^{176}$ Hale explained his disagreement with the decision in HALE, supra note 48 , at 134-35.

${ }^{177}$ McKinney, supra note 7, at 387.

${ }^{178}$ See, e.g., 4 BLACKSTONE, supra note 28, at *82 ("A bare conspiracy to levy war does not amount to this species of treason."); FOSTER, supra note 55, at 211 ("[E]very conspiracy to levy war for these purposes, [is] not treason within the clause of levying war."); HALE, supra note 48, at 131 ("[A] bare conspiracy or consultations of persons to levy a war, and to provide weapons for that purpose ... is not a levying of war within this clause of this statute."); HAWKINS, supra note 45 , at 38 ("[I]t is certain, that a bare conspiracy to levy such a war cannot amount to treason unless it be actually levied."). English law nonetheless recognized that a conspiracy to levy war could be considered an overt act for a charge of compassing the king's death. See 4 BLACKSTONE, supra note 28 , at *82 (" $[\mathrm{I}] \mathrm{f}$ [the conspiracy is] particularly pointed at the person of the king or his government[] it falls within ... compassing or imagining the king's death.”). 
nonetheless closely followed English law in defining the meaning of "levying war." Chief Justice Thomas McKean of Pennsylvania followed English authorities almost verbatim in charges to grand juries in the late 1770s. ${ }^{179}$ In his famous law lectures of 1790, James Wilson pointed out that "the term war cannot, in this place, mean such a one as is carried on between independent powers." Accordingly, "[a]ll the curious and extensive learning ... concerning the laws of war as carried on between separate nations, must be thrown out of this question." ${ }^{181}$ War in this context meant "war as is levied by those who owe obedience." 182 Wilson's subsequent analysis relied heavily on the treatises of Coke, Hale, Hawkins, Foster, and Blackstone. ${ }^{183}$ He reiterated that although levying war for some private purpose was not treason within the constitutional definition,

[i]nsurrections in order to throw down all inclosures, to open all prisons, to enhance the price of all labour, to expel foreigners in general, or those from any single nation living under the protection of government, to alter the established law, or to render it ineffectual-insurrections to accomplish these ends, by numbers and an open and armed force, are a levying of war against the United States. ${ }^{184}$

Wilson also noted that the line between treason and an aggravated riot "is sometimes very fine and difficult to be distinguished."

\section{The Whiskey Rebellion}

In 1794, serious opposition to the federal excise tax broke out in western Pennsylvania. This opposition, known as the "Whiskey Rebellion," was the first significant internal threat to the authority of the new federal government under the Constitution. After federal troops suppressed the rebellion, twenty men were brought to Philadelphia to

${ }^{179}$ See Thomas McKean, Notes of Charges Delivered to Grand Juries by Chief Justice Thomas McKean, 1777-1779, at 25-27 (unpublished manuscript, on file with the Historical Society of Pennsylvania). In several places in this manuscript, McKean has replaced "President of the Supreme Executive Council" with "Governor," which suggests that he was still using these charges after the adoption of the Pennsylvania Constitution of 1790. For a printed version of a typical charge, see THOMAS MCKEAN, A Charge Delivered to THE Grand JuRY (Lancaster, Pa., Francis Bailey 1778).

${ }^{180} 2$ WILSON, supra note 34 , at 667.

${ }^{181} I d$.

${ }^{182} I d$.

${ }^{183} I d$. at $667-68$.

${ }^{184} I d$. at 668 .

${ }^{185} \mathrm{Id}$. 
stand trial for treason. ${ }^{186}$ Only two men, John Mitchell and Philip Vigol, were ultimately convicted, although both were later pardoned by President Washington. ${ }^{187}$ Supreme Court Justice William Paterson presided over the trials. His charge to the grand jury offered a definition of levying war that was grounded in English precedents: "All persons, who rise in rebellion, and take up arms against the government, or who in a violent and forcible manner resist and prevent the regular administration of justice, and due execution of the laws, come within the description of levying war." It was equally treasonous to "make insurrections under the pretense of redressing national or public grievances" or to "attempt, by intimidation and violence, to force the repeal of a law, or an alteration in governmental measures." ${ }^{189}$ Paterson gave as examples insurrections "with an avowed design to pull down all inclosures" or "to open all prisons."

Similarly, Justice Paterson's charge to the petit jury in Mitchell's case concluded that if the object of the insurrection "was to suppress the excise offices, and to prevent the execution of an act of Congress, by force and intimidation, the offence, in legal estimation, is high treason; it is an usurpation of the authority of government; it is high treason by levying of war." ${ }^{191}$ Justice Paterson thought that the evidence showed this to be the object, and the jury accordingly convicted. ${ }^{192}$

${ }^{186}$ Thomas P. Slaughter, The Whiskey Rebellion: Frontier EPILOGUE TO THE AMERICAN REVOLUTION 219 (1986).

${ }^{187}$ See CHAPIN, supra note 7, at 87-90 (describing the trial of both men and their eventual pardons). The trials were likely something of an embarrassment to the Washington administration. In one case, for example, "[a]fter a long examination of witnesses it was discovered, that the defendant . . . was not the person, liable to the charge, but another person of the same name ...." United States v. Porter, 27 F. Cas. 597, 598 (C.C.D. Pa. 1795) (No. 16,073).

${ }^{188}$ William Paterson, Charge to the Grand Jury of the Circuit Court for the District of Pennsylvania (May 4, 1795), in 3 The Documentary History of THE Supreme CourT OF THE United StaTes, 1789-1800, at 40, 41 (Maeva Marcus ed., 1990) [hereinafter DOCUMENTARY HISTORY].

${ }^{189} I d$.

${ }^{190}$ Id. at 42.

${ }^{191}$ United States v. Mitchell, 26 F. Cas. 1277, 1281 (Paterson, Circuit Justice, C.C.D. Pa. 1795) (No. 15,788).

${ }^{192}$ See $i d$. at 1281-82 for Justice Paterson's analysis of the evidence and the jury's verdict. The Vigol prosecution did not involve any significant discussion of levying of war. The defendant was charged with participating in an attack on the home of an excise officer, forcing the officer to surrender his official papers, and extorting an oath from him that he could never again act to enforce the excise tax. United States v. Vigol, 28 F. Cas. 376, 376 (Paterson, Circuit Justice, C.C.D. Pa. 1795) (No. 16,621). These acts are further described in SLAUGHTER, supra note 186, at 150-51, 158. Justice 


\section{The Fries Rebellion}

The so-called "Fries Rebellion" of 1799 arose out of opposition to a property tax enacted by Congress in $1798 .{ }^{193}$ Federal tax assessors in several Pennsylvania counties encountered significant threats and harassment. ${ }^{194}$ After a federal marshal arrested a number of the protestors, a large armed mob, led by John Fries, confronted the marshal and successfully demanded their release. ${ }^{195}$ Fries and many of his confederates were subsequently indicted for treason by levying war against the United States. ${ }^{196}$

Fries's first trial for treason was held in 1799, with Justice Iredell and District Judge Peters presiding. Justice Iredell's charge to the grand jury stated that if "the intention was to prevent by force of arms the execution of any act of the congress of the United States altogether . . . any forcible opposition calculated to carry that intention into effect, was a levying of war against the United States." 197 By contrast, "if the intention was merely to defeat its operation in a particular instance" because of "some private or personal motive," the defendants' actions would not amount to treason. ${ }^{198}$

Fries's counsel would subsequently argue that English authorities should generally carry little weight in America, and offered a different

Paterson instructed the jury that the evidence showed that the object of the insurrection was clearly "to render null and void ... a an act of Congress" and that "the crime of high treason" was thereby established within the meaning of the Constitution. Vigol, 28 F. Cas. at 376. The jury did not take Justice Paterson as the last word on the law, however. In the middle of its deliberations, the jury requested a copy of Foster's Crown Law and Acts of Congress, which the court provided to them. Id. at 377. The eighteenth-century criminal jury, which the Framers of the Constitution took such pains to protect, was obviously a very different institution than its twenty-first-century descendant.

${ }^{193}$ See generally Paul Douglas Newman, Fries's Rebellion: The Enduring STRUGGLE FOR THE AMERICAN REVOLUTION, at xii (2004) (discussing the impetus for rebellion and the resistors' strong belief in popular sovereignty); Dwight F. Henderson, Treason, Sedition, and Fries' Rebellion, 14 AM. J. LEGAL HIST. 308, 309-11 (1970) (describing citizen resentment of the Direct Tax Act of 1798 and the events leading to rebellion); Stephen B. Presser, A Tale of Two Judges: Richard Peters, Samuel Chase, and the Broken Promise of Federalist Jurisprudence, 73 Nw. U. L. REV. 26, 83-93 (1978) (discussing the background of the Fries Rebellion).

${ }^{194}$ See, e.g., Henderson, supra note 193, at 309 ("Assessors were threatened, intimidated, and generally prevented from performing their duty.”).

${ }^{195}$ Id. at $310-11$.

${ }^{196}$ Id. at 312.

${ }^{197}$ Case of Fries, 9 F. Cas. 826, 840 (Iredell, Circuit Justice, C.C.D. Pa. 1799) (No. 5126).

${ }^{198} I d$ 
definition of levying war. ${ }^{199}$ Under the defense's view, levying war could consist of only three acts: (1) arraying a body of armed men in a martial manner with a view toward ending the existence of government; (2) a throwing off of allegiance by one part of the Union from the other part; and (3) taking possession of the legislative or executive authority by force of arms to compel either of the departments of government to act in a particular way. ${ }^{200}$ This interpretation obviously precluded a treason conviction for mere forcible resistance to one particular law, even if animated by general, rather than private, concerns.

Judge Peters's and Justice Iredell's charges to the jury pointedly rejected the defense's theory. As Judge Peters explained, "persons who have none but a common interest with their fellow-citizens, to oppose or prevent, by force, numbers or intimidation, a public and general law of the United States, with intent to prevent its operation, or compel its repeal" is treason by levying war. ${ }^{201}$ Fries was accordingly convicted. ${ }^{202}$ Upon a showing that a juror had uttered statements inimical to Fries prior to the trial, however, the court vacated Fries's conviction and ordered a new trial. ${ }^{203}$

Fries's second treason trial was held in 1800 , this time with Judge Peters and Justice Samuel Chase presiding. ${ }^{204}$ Aware that the defense was likely to make arguments similar to those it had made in the first trial, the court issued a pretrial opinion on the meaning of levying of war. The opinion noted that although the jury had the ultimate power to decide all questions of law and fact, it was the duty of the court to offer its opinion on questions of law. ${ }^{205}$ It explained that "any insurrection or rising of any body of people, within the United States, to attain or effect, by force or violence, any object of a great public na-

199 See id. at 897 ("As we have enacted laws of our own, and have not extended the laws of England to this country, we must put our own construction upon them, and not the determination of an English court.").

${ }^{200} I d$. at 899.

${ }^{201} I d$. at 908. Justice Iredell, on the other hand, argued that the framers of the Constitution borrowed terms from British statutes on treason, and that accordingly "the English authorities and definition of those terms should be much respected." Id. at 912 .

${ }^{202}$ Id. at 916.

203 See id. at 916-23 (discussing the motion for a new trial). The motion is also reported at United States v. Fries, 3 Dall. 515, 518-19 (Iredell, Circuit Justice, C.C.D. Pa. 1799).

${ }^{204}$ Case of Fries, 9 F. Cas. 924, 927-28 (Chase, Circuit Justice, C.C.D. Pa. 1800) (No. 5127).

${ }^{205}$ Id. at 943 . 
ture, or of public and general (or national) concern, is a levying war against the United States." ${ }^{206}$ Moreover, "any such insurrection or rising to resist or to prevent by force or violence, the execution of any statute of the United States ... is a levying war against the United States." 207 The use of "military weapons" was not necessary, as "numbers may supply the want of military weapons." ${ }^{208}$ Furthermore, the "assembling [of] bodies of men, armed and arrayed in a warlike manner, for purposes only of a private nature, is not treason." 209

Since this ruling deprived the defense of its primary argument, the defense counsel withdrew from representation, contending that the court's prejudgment of the legal issue was unfair. Although Chase offered to withdraw his opinion, the defense counsel refused to return, and when Fries refused new counsel, Chase stated that the court would act as counsel for the prisoner. ${ }^{210}$ Fries was convicted again, but was subsequently pardoned by President John Adams, against the advice of Adams's cabinet. ${ }^{211}$ Chase's conduct at the Fries trial was the basis for one of the charges against him in his impeachment trial in $1805 .^{212}$

\section{The Burr Cases}

The most extensive analysis of "levying war" under American treason law appears in several proceedings concerning the alleged treason of former Vice President Aaron Burr. Burr and his associates were accused of planning attacks on Spanish Mexico, as well as on cities in the Louisiana Territory, with the purpose of revolutionizing the western United States and separating it from the eastern states. The ensuing legal proceedings produced several important decisions by Chief Justice John Marshall, one in his capacity as Chief Justice of the United States, and the rest in his capacity as trial judge in the case against Aaron Burr. ${ }^{213}$

206 Id. at $943-44$.

${ }^{207}$ Id. at 944.

${ }^{208} I d$.

${ }^{209} I d$. Justice Chase reiterated all of these points in his charge to the jury. Id. at 930.

${ }^{210}$ See 3 DOCUMENTARY HistORY, supra note 188, at 404.

${ }^{211} I d$.

${ }^{212}$ William H. REHNQUIST, GRAND INQUESTS: THE HISTORIC IMPEACHMENTS OF Justices SAMUel CHASE AND PRESIDENT ANDREW JOHNSON 27 (1992).

${ }^{213}$ For a concise overview of the Burr trials, see JEAN EDWARD SMITH, JOHN MARSHALL: DEFINER OF A NATION 352-74 (1996). Smith notes that Marshall "always con- 
The first decision, Ex parte Bollman, was a habeas petition brought by two of Burr's associates in the Supreme Court of the United States to challenge their committal for treason. ${ }^{214}$ The Court's opinion established two key principles. First, the Court held, consistent with English precedent, that mere conspiracy to levy war is not treason; war must actually be levied. ${ }^{215}$ The Court took pains to point out, however, that if war is actually levied, all persons who played a role in the conspiracy and performed "any part, however minute," are "to be considered as traitors." 216 Second, the Court held that it is an essential element of levying war that there "be an actual assemblage of men for the purpose of executing a treasonable design." ${ }^{217}$ Merely enlisting men for that purpose would not constitute treason. ${ }^{218}$ The Court never defined "treasonable design," since it concluded that the design of "overturn[ing] the government of the United States in New Orleans" was unquestionably treasonable. ${ }^{219}$ Under these principles, the Court concluded that there was insufficient evidence to justify a commitment of either man on a charge of treason. ${ }^{220}$

The other important decisions arose from Marshall's role as presiding judge in the subsequent trial of Aaron Burr. Marshall initially refused to commit Burr for treason, relying heavily on the reasoning in Bollman. As Marshall explained, "it is equally clear that an intention to commit treason is an offence entirely distinct from the actual commission of that crime. War can only be levied by the employment of actual force. Troops must be embodied, men must be assembled, in order to levy war." ${ }^{221}$ The government subsequently gathered evidence that various men had assembled at Blennerhassett's Island in the Ohio River, allegedly for the purpose of carrying out Burr's treasonable designs. This assembly was the overt act upon which Burr's indictment was based. Burr, however, was several hundred miles from

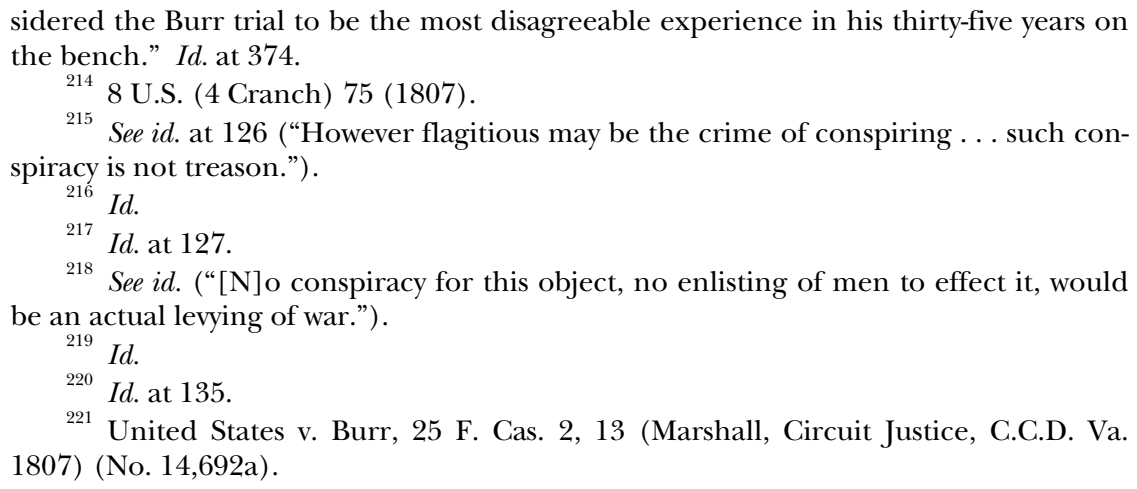

${ }^{221}$ United States v. Burr, 25 F. Cas. 2, 13 (Marshall, Circuit Justice, C.C.D. Va. 1807) (No. 14,692a). 
the island, and Burr's attorneys argued that he could not be convicted of treason for actions in which he did not personally participate. ${ }^{222}$ Moreover, they argued that the mere assemblage of men was insufficient to sustain a treason prosecution. The issue was argued extensively, ${ }^{223}$ and Marshall's decisions helped clarify certain issues from Bollman.

Marshall's grand jury charge distinguished between a conspiracy to levy war and an actual levying of war:

Any combination to subvert by force the government of the United States, violently to dismember the Union, to compel a change in the administration, to coerce the repeal or adoption of a general law, is a conspiracy to levy war; and if the conspiracy be carried into effect by the actual employment of force, by the embodying and assembling of men for the purpose of executing the treasonable design which was previously conceived, it amounts to levying of war. ${ }^{224}$

Later in the trial, Marshall emphasized again that the crime of "levying war" required the gathering of some sort of force, which would usually consist of the gathering of men. ${ }^{225}$ Such force need not necessarily be applied to a particular violent end, nor must the men necessarily be armed. Marshall argued that "[i]f a rebel army, avowing its hostility to the sovereign power . . . should march and countermarch before it . . . then disperse . . . without firing a gun," the marchers were clearly guilty of "levying war." ${ }^{226}$ Similarly, "[i]f the party be in a condition to execute the purposed treason without the usual implements of war," Marshall could "perceive no reason for requiring those implements in order to constitute the crime." ${ }^{227}$ Nonetheless, to levy war there had to be at least some "employment and exhibition of force.” ${ }^{228}$ Marshall took pains to explain that Bollman's requirement of an assemblage of men did not mean that a mere assemblage of men is sufficient; rather, the assemblage had to contain some element of

${ }^{222}$ United States v. Burr, 25 F. Cas. 55, 116 (Marshall, Circuit Justice, C.C.D. Va. 1807) (No. 14,693).

${ }^{223}$ See id. at $116-59$.

${ }^{224} I d$. at 168-69 (internal quotation marks omitted).

${ }^{225}$ See id. at 162 ("[The treasonous] character [of prior cases] was unequivocal, and was demonstrated by evidence furnished by the assemblage itself. . . A force is supposed to be collected for an avowed treasonable object, in a condition to attempt that object, and to have commenced the attempt by moving towards it.").

${ }^{226} I d$. at 162.

${ }^{227} I d$. effect).

${ }^{228}$ Id.; see also id. at 163-65 (citing English and American authorities to the same 
force. ${ }^{229}$ A "secret, unarmed meeting" was simply insufficient. ${ }^{230}$ Marshall also explained why an assemblage of men and a show of force was required. He asked, "Why is it that a single armed individual entering a boat, and sailing down the Ohio for the avowed purpose of attacking New Orleans, could not be said to levy war?" ${ }^{231}$ Marshall's answer was that such a person "is apparently not in a condition to levy war." ${ }^{232}$ If this is true, then "ought not the assemblage to furnish some evidence of its intention and capacity to levy war before it can amount to levying war?" 233 In 1807, of course, only an assemblage of men could wield significant force.

Marshall further held that in the absence of any evidence that Burr procured the assembly of men on Blennerhassett's Island, the government had to prove an actual overt act on Burr's part showing actual levying of war. That act, "may be minute, it may not be the actual appearance in arms, and it may be remote from the scene of action ... but it must be a part, and that part must be performed by a person who is leagued in the conspiracy.",234

\section{Subsequent American Decisions}

With a few isolated exceptions, the issue of treason by levying war almost entirely disappeared from American jurisprudence after the Burr trial. In 1808, a Vermonter was indicted for treason for forcibly removing a wooden raft from the custody of military guards assisting a federal revenue collector in the enforcement of the Embargo Act. ${ }^{235}$ Justice Henry Livingston's charge to the jury, relying on the opinions in the Whiskey Rebellion and Fries cases, all but directed an acquittal. ${ }^{236}$ Justice Livingston stated that the defendant's conduct was clearly of a private nature and that there was a significant difference between a true levying of war and a "sudden, transient, weak, unmili-

${ }^{229}$ See id. at 168 (“[A]lthough the terms force and violence are not employed [by the Supreme Court] as descriptions of the assemblage, such requisites are declared to be indispensable as can scarcely exist without the appearance of war and the existence of real force.").

${ }^{230}$ Id. at 168 .

${ }^{231} I d$. at 169.

${ }^{232} I d$.

${ }^{233} I d$.

${ }^{234} I d$. at 177.

${ }^{235}$ United States v. Hoxie, 26 F. Cas. 397 (Livingston, Circuit Justice, C.C.D. Vt. 1808) (No. 15,407).

${ }^{236}$ Id. at $399-400$. 
tary, and unsystematized resistance, and that in a solitary instance, and for the single object of personal emolument." ${ }^{237}$

In 1842, Justice Joseph Story defined "levying war" in a charge to a federal grand jury in Rhode Island. Story explained:

To constitute an actual levy of war, there must be an assembly of persons, met for the treasonable purpose, and some overt act done, or some attempt made by them with force to execute, or towards executing, that purpose. There must be a present intention to proceed in the execution of the treasonable purpose by force. ${ }^{238}$

An actual assault on the institutions of government was not required:

If the assembly is arrayed in a military manner, if they are armed and march in a military form, for the express purpose of overawing or intimidating the public, and thus they attempt to carry into effect the treasonable design, that will, of itself, amount to a levy of war, although no actual blow has been struck, or engagement has taken place. ${ }^{239}$

Story also elaborated on the meaning of "treasonable purpose." He emphasized that it was not necessary that "it should be a direct and positive intention entirely to subvert or overthrow the government." ${ }^{240}$ It was also treason "by force to prevent the execution of any one or more general and public laws of the government, or to resist the exercise of any legitimate authority of the government in its sovereign capacity." 241

${ }^{237} I d$. at 400. Similarly, in 1851 Justice Grier presided over a federal trial regarding a charge of treason for resisting individuals seeking to recover fugitive slaves pursuant to the Fugitive Slave Act. He charged the jury that he did "not think the transaction with which the prisoner is charged ... rises to the dignity of treason or a levying of war." United States v. Hanway, 26 F. Cas. 105, 128 (Grier, Circuit Justice, C.C.E.D. Pa. 1851) (No. 15,299). "[T] he object of the resistance must be of a public and general nature." Id. There was no evidence of a "previous conspiracy to make a general and public resistance to any law of the United States" and "no evidence that any person concerned in the transaction knew there were such acts of congress." Id. The defendant was acquitted. Id. at 129.

${ }^{238}$ Charge to the Grand Jury-Treason, 30 F. Cas. 1046, 1047 (Story, Circuit Justice, C.C.D.R.I. 1842) (No. 18,275).

${ }^{239} I d$

${ }^{240} I d$.

${ }^{241}$ Id. In 1844, Thomas Wilson Dorr was tried and convicted for treason by the state of Rhode Island for his role in leading the so-called "Dorr Rebellion." One of Dorr's arguments in defense was that he was acting as governor of the state under the "People's Constitution," and therefore lacked the necessary criminal intent to commit treason. See The Trial of Thomas Wilson Dorr for Treason, Rhode Island, 1844, in 2 AMERICAN STATE TRIALS 5, 117-18, 120 (John D. Lawson ed., 1914). The presiding judge relied verbatim on Justice Story's federal grand jury charge for the definition of levying war. See id. at 157-58. 
A 1911 Nevada statute explicitly defined "levying war" for purposes of the state's treason law. This appears to be the only statutory definition of "levying war" in an American jurisdiction. Under the statute,

[w] hen persons arise in insurrection with intent to prevent, in general, by force and intimidation, the execution of a statute of this state, or to force its repeal, they shall be guilty of levying war. But an endeavor, although by numbers and force of arms, to resist the execution of a law in a single instance, and for a private purpose, is not levying war. ${ }^{242}$

\section{Terrorism and Levying War}

The historical material recounted above poses a most difficult question: what is the current state of the law governing treason by levying war? In 1945, the leading American treason scholar, James Willard Hurst, argued that "the crime of treason by levying war has been restricted here ... to the offense described by the literal meaning of the words: a direct effort to overthrow the government, or wholly to supplant its authority in some part or all of its territory." 243 Specifically, Hurst believed there was no longer any vitality to the crime of treason by forcible resistance to particular laws. ${ }^{244}$ Hurst reasoned that the lack of prosecutions, despite such disturbances as "the railroad strikes of 1877, the Haymarket affair of 1886, Coxey's Army, and the Pullman strike in 1894," 245 showed that this area of law had "become obsolete by nonuse and by critical reaction against it at the bar and in the courts." ${ }^{246}$ Hurst's examples, however, do not convincingly prove his case, and it may be that clear instances of this form of treason simply have not occurred. Significantly, there is no American decision explicitly rejecting the view that forcible resistance to a particular law for public purposes is treason by levying war.

Resolution of this troublesome issue, however, is probably not necessary for most cases related to terrorism. Violent attacks of the sort that the United States experienced on September 11 are not directed at resisting one particular law; they contemplate the destruc-

${ }^{242}$ NEV. REV. STAT. ANN. § 196.020 (LexisNexis 2001).

${ }^{243}$ Willard Hurst, Treason in the United States (pt. 3), 58 HARV. L. REV. 806, 822-23 (1945).

${ }^{244}$ HURST, supra note 6, at ix.

${ }^{245}$ Hurst, supra note 243, at 822.

${ }^{246}$ HURST, supra note 6, at ix. 
tion and incapacitation of the entire United States government. ${ }^{247}$ The attack on the Pentagon and the potential attack on the Capitol or the White House present the easiest case for a finding of levying war. The terrorists assembled men and employed force directly against the United States government for public purposes. Indeed, if such attacks did not constitute levying war against the United States, it is hard to imagine what would. Even if the terrorists had attacked only the World Trade Center, however, their avowed purpose of altering the policies of the United States government ${ }^{248}$ would render their conduct treasonous. This connection between treason and terrorism was explicitly recognized in United States $v$. Rahman, an appeal of convictions for the 1993 World Trade Center bombing. ${ }^{249}$ The Second Circuit unanimously upheld the trial judge's application of the treason sentencing guideline, which provided the base offense level for "conduct [that] is tantamount to waging war against the United States." 250 As the court explained, "The evidence established that each defendant joined either the plot that resulted in the bombing of the World Trade Center or the plot to bomb major New York City tunnels and bridges . . . . Such activity . . could not be found to be other than conduct 'tantamount to waging war."”251 Under this view, Timothy McVeigh's 1995 assault on the federal building in Oklahoma City was also an act of treason by levying war against the United States.

The terrorist threats posed by modern technology also require reconsideration of Chief Justice Marshall's conclusion that a lone individual could not levy war. A solo pilot of a cargo plane wields the force of thousands of eighteenth-century men; an individual armed with a nuclear weapon wields the force of millions more. Such a person is in a position to deliver a single devastating blow to the operations of the United States government, a power no individual ever could have wielded prior to the twentieth century. Under any functional account of the law, such a person can be said to levy war against

${ }^{247}$ See Yoram Schweitzer \& SAul Shay, The Globalization of Terror: The CHALlENGE OF AL-QAidA AND THE RESPONSE OF THE INTERNATIONAL COMMUNITY 32 (2003) ("The chain of terror activities initiated by Bin-Laden was designed to deliver a strategic blow of terror that would significantly cripple the status and influence of the United States.”).

${ }^{248}$ See id. at 138 (proposing that one of the goals of the September 11 attack was to drag the United States into a war against the entire Muslim world).

249 F.3d 88, 103 (2d Cir. 1999).

${ }^{250} I d$. at 154 (quoting U.S. SENTENCING GuIDELINES MANUAL § 2M1.1(a)(1) (1998)).

${ }^{251} I d$. 
the United States; it would strain all credulity to assert, for example, that there must be at least two people in the cockpit of the plane in order for war to be levied.

Far from deviating from traditional understandings of levying war, many terrorist acts accordingly fit well within its meaning. Indeed, the larger and more horrific the terrorist action, the more likely that it will constitute an act of levying war. As such, it is very hard to argue that terrorism represents a significant exception to the ordinary criminal law paradigm. The worst terrorists are traitors, and should be punished as such.

Mere conspiracy to levy war, however, is not treason. Such conspiracies are governed instead by the federal statute prohibiting seditious conspiracies. ${ }^{252}$ To advance from a conspiracy to an actual levying of war, there must be some overt act and some show of force. Depending on the nature of the conspiracy, however, and the preparatory actions taken, it may be possible to show that a terrorist conspiracy constitutes treason by adhering to the enemies of the United States. It is to that subject that I now turn.

\section{ARE TERRORIST ORGANIZATIONS "ENEMIES?"}

The Treason Clause's second definition of treason focuses on enemies: "Treason against the United States, shall consist... in adhering to their Enemies, giving them Aid and Comfort." ${ }^{253}$ This definition raises two significant questions. First, what exactly does it mean to be an "enemy," and might certain terrorist organizations hostile to the United States be "enemies" under this provision? Second, regardless of how the term is to be defined, which institution of government is entrusted with that determination? Is this essentially a political question that is entrusted to the legislative and executive branches, or is it a question that courts can attempt to answer?

In Section A, I examine the English precedents interpreting the term "enemies" as well as the handful of American decisions that have addressed it. I conclude that certain terrorist organizations such as $\mathrm{Al}$ Qaeda can be considered "enemies" within the meaning of the Trea-

${ }^{252}$ See 18 U.S.C. $§ 2384$ (2000) (defining as seditious conspiracy acts by "two or more persons in any State or Territory, or in any place subject to the jurisdiction of the United States, [to] conspire to overthrow, put down, or to destroy by force the Government of the United States, or to levy war against them"); see also Rahman, 189 F.3d at 111-14 (distinguishing seditious conspiracy under the federal statute from treason under the Constitution).

${ }^{253}$ U.S. CONST. art. III, § 3. 
son Clause. In Section B, I address the separate question of institutional competence. I conclude that courts have an important supervisory role to play with respect to this issue, but that substantial deference is owed to the legislative and executive branches.

\section{A. The Definition of "Enemies"}

Unlike the term "war," which is peppered throughout the Constitution, ${ }^{254}$ the term "enemies" appears only in the Treason Clause and in Section 3 of the Fourteenth Amendment, which substantially tracks the Treason Clause. ${ }^{255}$ As with the levying war provision, however, the adhering-to-enemies provision is taken directly from the English statute of 25 Edward III. ${ }^{256}$ It is therefore instructive to examine the meaning of the term "enemies" under English law as it was understood at the time of the ratification of the Constitution. The following broad propositions were largely undisputed.

First, the enemies provision served as the foreign counterpart to the levying war provision, and the two provisions define, respectively, external and internal treason. Accordingly, English subjects could never be enemies under 25 Edward III, even if they were engaged in open rebellion against the king. As Coke explained, "Inimicus in legal understanding is hostis, for the subjects of the king, though they be in open war or rebellion against the king, yet are they not the king's enemies, but traitors; for enemies be those that be out of the allegiance of the king." ${ }^{257}$ Or, as Blackstone put it, an enemy is "always the subject of some foreign pri[n]ce, and one who owes no allegiance to the crown of England." 258 A 1768 American edition of an English treatise summarized the law thusly:

${ }^{254}$ See, e.g., U.S. CONST. art. I, $\$ 8$ (enumerating the congressional power " $[\mathrm{t}] \mathrm{o}$ declare War").

${ }^{255}$ See U.S. CONST. amend. XIV, § 3 ("No person shall . . hold any office, civil or military, under the United States, or under any State, who, having previously taken an oath, ... shall have engaged in insurrection or rebellion against the same, or given aid or comfort to the enemies thereof.").

${ }^{256}$ See Treason Act, 1351, 25 Edw. 3, stat. 5, c. 2 (declaring it to be treasonous "if a man do levy war against our lord the king in his realm, or be adherent to the king's enemies in his realm, giving to them aid and comfort in the realm, or elsewhere").

${ }^{257}$ COKE, supra note 19 , at 11 (italics added).

2584 BLACKSTONe, supra note 28 , at $* 83$; see also HALE, supra note 48 , at 159 (stating that only foreigners "come properly under the name of enemies"); HAWKINS, supra note 45 , at 38 (linking enemies to "aliens in open hostility against the king" and noting that "a rebel is not properly an enemy"). 
Subjects of the king, in open war, or rebellion, are not the king's enemies, but traitors; and if a subject join with a foreign enemy, and come into England with him; if he be taken prisoner, he shall not be ransomed, or proceeded against as an enemy, but as a traitor to the king: but an enemy coming in open hostility into this kingdom and taken, shall be either executed by martial law, or ransomed; for he cannot be indicted of treason, because he never was within the allegiance of the king. ${ }^{259}$

Second, "enemies" was not limited only to those foreign states against which England had declared war. Courts looked to the fact of actual hostility, not to formalities. ${ }^{260}$ Foster concluded, "[s] tates in actual hostility with us, though no war be solemnly declared, are enemies within the meaning of the Act." ${ }^{261}$

Third, "enemies" was not limited to states, and could include rogue groups of individuals with hostile designs against England. The classic example was a foreigner who attacked England on his own initiative, notwithstanding peaceful relations between his country and England. "[I]f the subject of a foreign prince in amity with us invades the kingdom without commission from his sovereign," Foster explained, "he is an enemy." "262 Similarly, as Blackstone noted, "foreign pirates or robbers, who may happen to invade our coasts, without any open hostilities between their nation and our own" are properly classified as enemies under the treason statute. ${ }^{263}$

Although the evidence is limited, these English definitions appear to have been widely accepted in late eighteenth-century America. In the late 1770s, Chief Justice Thomas McKean of Pennsylvania interpreted the term "enemies" in his state's treason law in accordance with English precedents:

259 EVERY MAN His OWN LAWYER, supra note 172, at 266-67 (emphasis omitted). Similarly, a 1787 New York edition of Vattel's famous treatise on international law asserted that deserters to the enemy "are not properly considered as enemies, and are rather perfidious citizens, traitors to their country, and this quality, their enlisting with the enemy cannot obliterate, nor exempt them from the punishment they have deserved.” VATTEL, The LAW OF NATIONS (New York, Berry \& Roger 1787).

${ }^{260}$ See, e.g., HALE, supra note 48, at 162 ("[I]f de facto there be a war between princes, they and their subjects are in a state of hostility and they are in the condition of enemies ... to each other....").

${ }^{261}$ FOSTER, supra note 55, at 219; see also 4 BLACKSTONE, supra note 28 , at *83 (stating that an enemy is always "one who owes no allegiance to the crown of England").

${ }^{262}$ FOSTER, supra note 55, at 219.

2634 BLACKSTONE, supra note 28 , at $* 83$; see also HALE, supra note 48 , at 164 ("[E]nemy extends farther than a king or state in enmity, [and includes] an alien coming into England in hostility." (emphasis omitted)). 
States in actual hostility with the United States of America, though no war be solemnly declared, are enemies within the meaning of this Act. And if the subject of any foreign prince in amity with us invades any of these United States, without commission from his sovereign, he is an enemy. Or if an alien army acts in a hostile manner against us, under a commission from a prince or state at enmity with us, he is an enemy. And aiding or assisting either of them is treason within this clause. ${ }^{264}$

In his law lectures of 1790, James Wilson, citing Foster, similarly observed that "the subjects or citizens of such states or princes, in actual hostility, though no war be solemnly declared, are . . enemies." 265

In 1798, Attorney General Charles Lee analyzed the deteriorating relationship between the United States and France. Although no formal declaration of war had issued, he concluded in a formal opinion that there existed an actual maritime war, authorized by the governments of both nations. ${ }^{266}$ Accordingly, he reasoned, "France is our enemy; and to aid, assist, and abet that nation in her maritime warfare, will be treason in a citizen or any other person within the United States not commissioned under France." ${ }^{267}$ Lee observed that there were reports of a Frenchman somewhere in the United States who was buying ships and supplies for French use in the West Indies. ${ }^{268}$ This individual, Lee recommended, "should be apprehended and tried as a traitor, unless he has a commission, and acts according to it; in which case he should be treated as an enemy, and confined as a prisoner of war." $" 269$

Subsequent American decisions squarely addressing the meaning of the term "enemies" in the context of the Treason Clause are extremely rare. ${ }^{270}$ Nonetheless, there is little reason to believe that

264 McKean, supra note 179, at 29.

2652 WiLSON, supra note 34, at 668.

${ }^{266} 1$ Op. Att'y Gen. 84, 84 (1798).

267 Id.

268 Id. at 85 .

269 Id.

${ }^{270}$ A consistent line of cases holds that a United States citizen who remains in enemy territory after the initiation of hostilities may be treated as an enemy, at least insofar as seizure of his property by the military in wartime is concerned. See, e.g., Juragua Iron Co. v. United States, 212 U.S. 297, 306 (1909) ("The plaintiff, although an American corporation, doing business in Cuba, was, during the war with Spain, to be deemed an enemy to the United States with respect of its property found and then used in that country...."); Gates v. Goodloe, 101 U.S. 612, 617 (1880) ("When [R.C. Brinkley] abandoned his home, and entered the military lines of the enemy, he was, beyond question, ... an enemy of the government . . . liable to be treated as such both to his person and property.”); Miller v. United States, 78 U.S. (11 Wall.) 268, 305-06 (1871) ("It is immaterial to it whether the owner [of the confiscated property] be an alien or a 
American law has departed in any significant respect from this early understanding of the term. ${ }^{271}$ Our view of the law, however, can be easily obscured by overhasty readings of the Supreme Court's extensive discussion of the term "enemies" in The Prize Cases. ${ }^{272}$ These cases concerned the Union blockade of Confederate ports, the legality of which depended upon the Confederacy's status as a belligerent under principles of international law. As the Court explained, " $[w]$ hen the party in rebellion occupy and hold in a hostile manner a certain portion of territory; have declared their independence; have cast off their allegiance; have organized armies; have commenced hostilities against their former sovereign, the world acknowledges them as belligerents, and the contest a war." ${ }^{273}$ The parties to a civil war "usually concede to each other belligerent rights. They exchange prisoners, and adopt the other courtesies and rules common to public or national wars." ${ }^{274}$ The specific question before the Court was whether President Lincoln could unilaterally recognize a state of war with the Confederacy absent congressional action. ${ }^{275}$ In the course of the argument, however, counsel for the claimants asserted that the Confederacy, at least in the early stages of the Civil War, was not entitled to belligerent status under any circumstances, since the events constituted only an insurrection, not a war. ${ }^{276}$ The Court held that the "law of nations . . contains no such anomalous doctrine." ${ }^{277}$ It was inconceivable that

insurgents who have risen in rebellion against their sovereign, expelled her Courts, established a revolutionary government, organized armies,

friend .... In either case the property may be liable to confiscation under the rules of war."); The Venus, 12 U.S. (8 Cranch) 253, 286 (1814) (noting that a citizen's property may be condemned in the midst of hostilities if that citizen was a "belligerent" at the time of the condemnation). These cases, however, have rested on general international law principles and not on the Treason Clause. Other cases have interpreted the term "enemy" as defined in the Trading with the Enemy Act of 1917, 50 U.S.C. App. $\S$ $2(2000)$.

${ }^{271}$ See, e.g., Martin v. Young, 134 F. Supp. 204, 207 (N.D. Cal. 1955) (suggesting that North Korea, although not the subject of a declaration of war, was an enemy for purposes of the federal treason statute).

${ }^{272} 67$ U.S. (2 Black) 635 (1863).

${ }^{273}$ Id. at 666-67; see generally Yair M. Lootsteen, The Concept of Belligerency in International Law, 166 MIL. L. REV. 109 (2000) (discussing the application of concepts of belligerency to armed conflicts under international law and the significance of holding territory). For a cogent analysis of constitutional issues raised by the Civil War, see DANIEL FARBER, LINCOLN'S CONSTITUTION (2003).

${ }^{274}$ The Prize Cases, 67 U.S. (2 Black) at 667.

${ }^{275} I d$. at 665 .

${ }^{276} I d$. at 642-43 (argument of Attorney Carlisle).

${ }^{277} I d$. at 670 . 
and commenced hostilities, are not enemies because they are traitors; and a war levied on the Government by traitors, in order to dismember and destroy it, is not a war because it is an "insurrection." 278

Having established the legality of the blockade, the Court turned to the meaning of the term "enemies' property" under the law of war. ${ }^{279}$ The Court noted that the claimants, relying on common law, "contend that the term 'enemy' is properly applicable to those only who are subjects or citizens of a foreign state at war with our own." 280 Such an argument, the Court held, was entirely inconsistent with the concept of belligerency under international law. The claimant's proposition suggested that the Confederacy could exercise belligerent rights against the Union, but that the Union could not do so against the Confederacy. ${ }^{281}$ Under international law, enemies' property was subject to capture; here, the Confederate rebels had "cast off their allegiance and made war on their Government, and are none the less enemies because they are traitors." 282

The Court's willingness to twice equate "enemies" with "traitors" might suggest an abandonment of the traditional distinction under treason law between "enemies" and "traitors." Such an interpretation of The Prize Cases, however, is unwarranted. First, the Court was careful to explain that its holding rested on principles of international law, and, in particular, on principles uniquely applicable to admiralty jurisdiction. As the Court explained, "in defining the meaning of the term 'enemies' property,' we will be led into error if we refer to Fleta and Lord Coke.... It is a technical phrase peculiar to prize courts, and depends upon principles of public policy as distinguished from the common law." 283 Second, the Court's reasoning must be read in light of the sweeping argument offered by the claimants, which sought to apply treason law principles in a manner that would eliminate the power of parties to a civil war to recognize the traditional status of belligerency. Third, seven months after The Prize Cases were decided, Justice Stephen Field followed traditional treason law principles when instructing a jury on circuit, stating:

The term "enemies," as used in the second clause [of the Treason

Clause], according to its settled meaning, at the time the constitution

278 Id

279 Id. at 671.

${ }^{280}$ Id. at 672.

281 Id. at 673.

${ }^{282}$ Id. at 674.

283 Id. 
was adopted, applies only to the subjects of a foreign power in a state of open hostility with us. It does not embrace rebels in insurrection against their own government. An enemy is always the subject of a foreign power who owes no allegiance to our government or country. ${ }^{284}$

Surely if The Prize Cases constituted a major innovation in treason law, Justice Field would have noted that. Rather, his restatement of traditional principles indicates that the term "enemies" in the Constitution retains its widespread and traditional meaning.

The foregoing authorities suggest that Al Qaeda and possibly other terrorist groups might constitute "enemies" within the meaning of the Treason Clause. The most apt analogy is between Al Qaeda and the "pirates and robbers" that Blackstone recognized as "enemies" under English treason law. And just as a rogue French nobleman with independent designs to attack England would constitute an enemy of England, a rogue Saudi millionaire with plans to attack the United States is an enemy of the United States. There can be no doubt that $\mathrm{Al}$ Qaeda has engaged in violent, war-like attacks on the United States. In this regard, Al Qaeda differs significantly from the Soviet Union during the Cold War period. The Soviet Union was never an "enemy" of the United States under the Treason Clause because it was never at open war with the United States. Accordingly, persons who allegedly spied for the Soviet Union, such as Julius and Ethel Rosenberg, were convicted of espionage, not treason. ${ }^{285}$

\section{B. By Whom and How Should Enemy Status Be Determined?}

If foreign terrorist organizations may constitute "enemies" under the Treason Clause, the next question is, who gets to make this determination? The issue is likely to arise in the following way: the federal government indicts an individual for treason on the basis of providing aid and comfort to a foreign terrorist group, and the defendant moves to dismiss the indictment on the ground that the terrorist organization is not an "enemy" within the meaning of the Treason Clause.

There is a significant argument that such a determination poses a nonreviewable political question. As a practical matter, declaring a

\footnotetext{
${ }^{284}$ United States v. Greathouse, 26 F. Cas. 18, 22 (Field, Circuit Justice, C.C.N.D. Cal. 1863) (No. 15,254).

${ }^{285}$ See United States v. Rosenberg, 195 F.2d 583, 588-90 (2d Cir. 1952) (discussing the grand jury indictment and conviction of the Rosenbergs for violating the Espionage Act).
} 
nation or a group to be an "enemy" is tantamount to a declaration of war. Such a determination therefore raises thorny questions of foreign relations that the text of the Constitution squarely commits to the political branches. ${ }^{286}$ The Supreme Court has emphasized that such questions of foreign affairs are particularly inappropriate for judicial resolution, ${ }^{287}$ and it seems at minimum unseemly for courts to interfere with such determinations. Although there appear to be no American decisions addressing this issue in the context of the Treason Clause, there are several instructive decisions in other contexts. In The Prize Cases, the Supreme Court held that the question of whether a rebellion was of sufficient magnitude to justify recognition of belligerent status was "a question to be decided by [the President], and this Court must be governed by the decisions and acts of the political department of the Government to which this power was entrusted." ${ }^{288}$ President Lincoln's proclamation of the blockade was "official and conclusive evidence to the Court that a state of war existed." ${ }^{289}$ A slightly earlier district court case had held, "In a legal sense, the state of war or peace is not a question in pais for courts to determine. It is a legal fact ascertainable only from the decision of the political department." ${ }^{290}$ Both decisions suggest that, as an evidentiary matter, the existence of a state of war is a matter of judicial notice of the actions of the political branches, an idea that subsequent lower court decisions have explicitly embraced. ${ }^{291}$ These decisions have empha-

${ }^{286}$ See Baker v. Carr, 369 U.S. 186, 217 (1962) (noting, among the potential reasons for determining an issue to be a "political question," the possibility of "a textually demonstrable constitutional commitment of the issue to a coordinate political department”); see also U.S. CONST. art. I, $\S 8$, cl. 11 (granting Congress the power “[t]o declare War").

${ }_{287}$ See Oetjen v. Cent. Leather Co., 246 U.S. 297, 302 (1918) ("The conduct of the foreign relations of our Government is committed by the Constitution to the Executive and Legislative-'the political'-Departments of the Government, and the propriety of what may be done in the exercise of this political power is not subject to judicial inquiry or decision.").

${ }^{288} 67$ U.S. (2 Black) 635, 670 (1863).

${ }^{289} I d$.

${ }^{290}$ United States v. One Hundred \& Twenty-Nine Packages, 27 F. Cas. 284, 289 (E.D. Mo. 1862) (No. 15,941).

${ }^{291}$ See, e.g., Grewe v. France, 75 F. Supp. 433, 437 (E.D. Wis. 1948) ("This court will take judicial notice of the fact that in June and July, 1946, a state of war existed between this nation and that of Germany ...."); United States v. Greathouse, 26 F. Cas. 18, 23 (Field, Circuit Justice, C.C.N.D. Cal. 1863) (No. 15,524) ("The existence of the rebellion is a matter of public notoriety, and . . may be taken notice of by judges and juries .... The public notoriety, the proclamations of the president, and the acts of congress are sufficient proof of the allegation of the indictment in this respect."). 
sized that "there must be some determination by the political department of the government evidencing the existence of" a state of war. ${ }^{292}$ As one court explained, " $[u]$ ntil some recognition by the political department, express, implied, or tacit, of new conditions in foreign states, there is no 'open war,' no 'belligerent;' there are no 'enemies' that the court can recognize, but only insurgents." ${ }^{293}$

Although these decisions might suggest that the determination of "enemy" status is completely unreviewable by courts, such an argument must certainly fail, at least with respect to the Treason Clause. A court surely can and must dismiss a treason indictment if the asserted "enemy" was the Democratic Party or the Sierra Club or the Chicago Tribune. Indeed, the location of the Treason Clause in Article III is strong evidence that the clause is a directive to the judicial branch to review treason indictments and prosecutions carefully to guard against executive abuse. If a defendant were precluded from arguing that the alleged "enemy" isn't anything of the sort, the protective safeguards of the Treason Clause could be easily evaded. The problem, though, perhaps peculiar to the law of treason, is to fashion a standard that is protective of defendants while not unduly interfering with the political branches' conduct of foreign affairs.

${ }^{292}$ Verano v. De Angelis Coal Co., 41 F. Supp. 954, 955 (M.D. Pa. 1941) (holding that there was no state of war between the United States and Italy); see also Semmes v. City Fire Ins. Co., 21 F. Cas. 1051, 1054 (C.C.D. Conn. 1869) (No. 12,651) ("It is a settled rule with the courts of the United States, in ascertaining whether or not war exists, to look to the action of those departments of the government to which that subject is confided by the constitution."), rev'd on other grounds sub nom. Semmes v. Hartford Ins. Co., 80 U.S. (13 Wall.) 158 (1871); cf. Langlas v. Iowa Life Ins. Co., 63 N.W.2d 885, 889 (Iowa 1954) ("[W]ar is a fact, not dependent upon the formal declaration of Congress.”); La Rue v. Kan. Mut. Life Ins. Co., 75 P. 494, 496 (Kan. 1904) (taking judicial notice of the insurrection in the Philippine Islands as a "fact in history"); Dole v. Merchants' Mut. Marine Ins. Co., 51 Me. 465, 470 (1863) ("War is an existing fact, and not a legislative decree. . . . [I]t is the fact that makes 'enemies,' and not any legislative Act.”). But see Pang v. Sun Life Assurance Co. of Can., 37 Haw. 208, 216, 222 (1945) (holding that the attack on Pearl Harbor, although an act of war, did not create a state of war under the terms of a life insurance policy).

${ }^{293}$ The Ambrose Light, 25 F. 408, 420 (S.D.N.Y. 1885). Similar reasoning likely applies to the recognition of the conclusion of hostilities. As the Supreme Court put it in 1948, "[w] hether and when it would be open to this Court to find that a war though merely formally kept alive had in fact ended, is a question too fraught with gravity even to be adequately formulated when not compelled." Ludecke v. Watkins, 335 U.S. 160, 169 (1948); cf. Ex parte Arakawa, 79 F. Supp. 468, 470-71 (E.D. Pa. 1947) (holding that the Axis powers' unconditional surrender and the President's proclamation of cessation of hostilities did not terminate the state of war). 
At minimum, the Treason Clause would seem to demand review of two issues: (1) whether the asserted "enemy" at least conforms to the traditional requirement that an "enemy" have no allegiance to the United States; and (2) whether the assertion is supported by other actions of the political departments. As a basic matter of due process, individuals should have some sort of notice as to what groups will be considered enemies for purposes of the Treason Clause. The declaration of enemy status cannot come in the indictment itself. By limiting judicial inquiry to these two narrow questions, the traditional prerogatives of the political branches over foreign affairs would be maintained, while at the same time preserving the protective purposes of the Treason Clause. ${ }^{294}$

\section{Al Qaeda as Enemy}

If the foregoing analysis is correct, can terrorist organizations currently be recognized as "enemies" under the Treason Clause? With respect to Al Qaeda, the answer is likely yes. Shortly after the September 11 attacks, Congress passed an act authorizing the President "to use all necessary and appropriate force against those nations, organizations, or persons he determines planned, authorized, committed, or aided the terrorist attacks that occurred on September 11, 2001, or harbored such organizations or persons." ${ }^{295}$ Congress further asserted that "such [terrorist] acts continue to pose an unusual and extraordinary threat to the national security and foreign policy of the United States." ${ }^{296}$ This resolution clearly singles out any group responsible for the September 11 attacks as the appropriate target of full-scale military force and contemplates action by the United States armed forces. ${ }^{297}$ A forceful argument can therefore be made that the political branches have identified the perpetrators of the September 11 attacks as public enemies of the United States. The argument would be stronger, of course, if Congress had specifically used the word "ene-

${ }^{294}$ Cf. Moyer v. Peabody, 212 U.S. 78, 85 (1909) (holding that the Colorado Governor was not liable for damages for detaining an individual after declaring a county to be in a state of insurrection so long as he acted in good faith and with the honest belief that the actions were necessary).

${ }^{295}$ Authorization for Use of Military Force, Pub. L. No. 107-40, 115 Stat. 224, 224 (2001).

${ }^{296} I d$. For an analysis of this legislation, see Michael Stokes Paulsen, Youngstown Goes to War, 19 CONST. COMMENT. 215, 250-57 (2002).

297 Cf. Curtis A. Bradley \& Jack L. Goldsmith, Congressional Authorization and the War on Terrorism, 118 HARV. L. REV. 2047, 2107-16 (2005) (discussing who may be considered an "enemy" under the resolution). 
mies." Were Congress to do so, it would be nearly impossible for a court to hold that $\mathrm{Al}$ Qaeda is not an enemy for purposes of the Treason Clause. ${ }^{298}$

It should be noted that such a decision to declare $\mathrm{Al}$ Qaeda an enemy may have repercussions for the federal statutes prohibiting the provision of material support to a terrorist organization. ${ }^{299}$ If $\mathrm{Al}$ Qaeda is an enemy, the Treason Clause may preclude prosecution under the terrorist support statutes, because the elements of the crime would be identical with that of adhering to the enemies of the United States by giving them aid and comfort. An individual prosecuted under these statutes would have a valid defense that the terrorist organization allegedly aided was in fact an "enemy" under the Treason Clause. ${ }^{300}$ Such a defense would force the government to either abandon the material support prosecution or concede that $\mathrm{Al}$ Qaeda is not an "enemy."

This analysis also suggests that someone who aided Al Qaeda prior to September 11 could not be indicted for treason by adhering to enemies, ${ }^{301}$ although depending upon the level of involvement in the plot, could be susceptible to a charge of treason by levying war. With respect to other terrorist organizations, the argument for "enemy" status is much more doubtful. These organizations have not been specifically singled out for the use of military force by Congress, and any treason prosecution for assisting such organizations would raise troublesome issues of notice and due process.

Traditional treason law principles, in short, support viewing certain terrorist groups as enemies of the United States. As with levying

${ }^{298}$ The potential power of the President to recognize "enemy" status unilaterally is an issue that raises complex questions of presidential war power vis-à-vis Congress that are far beyond the scope of this Article.

${ }^{299}$ See, e.g., 18 U.S.C. \$ 2339A-2339B (2000) (making it a criminal offense to provide material support of resources to terrorist groups). For a thorough analysis of these laws, see generally Robert M. Chesney, The Sleeper Scenario: Terrorism-Support Laws and the Demands of Prevention, 42 HARV. J. ON LEGIS. 1 (2005).

${ }^{300}$ Cf. Cramer v. United States, 325 U.S. 1, 45 (1945) (suggesting "that Congress could [not] dispense with the two-witness rule merely by giving the same offense another name").

${ }^{301}$ The requirement of prior open recognition of enemy status was recognized under English law. As Foster explained,

[t] he offence of inciting foreigners to invade the kingdom is a treason of sig-

nal enormity. ... And yet, unless the powers so incited happen to be actually

at war with us at the time of such incitement, the offence will not fall within any branch of the Statute of Treasons, except that of compassing the king's death.

FOSTER, supra note 55, at 196-97. 
war, there is therefore little reason to think that terrorist groups pose such a distinctive and unique threat as to warrant departure from the ordinary criminal law paradigm.

\section{CONCLUSION}

The title of this Article refers to "the forgotten constitutional law of treason." As I suggested in the Introduction, the sources and issues recounted in this Article are likely unfamiliar to most lawyers and scholars. Yet the Treason Clause forms an important part of American constitutional law. Through the Treason Clause, the Framers confirmed the long-standing practice in Anglo-American law of distinguishing between persons subject to the law of treason and persons subject to military authority, a practice now seriously eroded by the Supreme Court's ratification of the Quirin error in Hamdi. This lesson is particularly meaningful in an age of terrorism. The worst forms of terrorist activity, far from presenting an appropriate military exception to the criminal law paradigm, in fact fit comfortably within traditional notions of treason-treason that must be punished in accordance with the provisions of Article III.

Forgetting the law of treason, of course, is a luxury of stable societies. For the most part, we are not plagued by enemy invasions or by violent internal insurrections. When confronted with crisis, it thus becomes easy to overlook the Treason Clause or to dismiss it as a remnant of the age of the musket, with little relevance to the dangers of a modern nuclear world.

The Treason Clause, however, is not the product of an age of peace and tranquility. The revolutionary generation that enshrined it in our Constitution had just emerged from a tumultuous, bloody civil war that pitted neighbor against neighbor and brother against brother. Over six years of land combat and naval operations had resulted in thousands of deaths, and the maiming and mutilation of thousands more. The overthrow of a government by force and violence was not a theoretical possibility, but the very outcome of the Revolution itself. Shortly before the Constitutional Convention began, Shays's Rebellion broke out in western Massachusetts, raising the question of whether state governments themselves were secure, much less the fledgling national government. In short, the Framers lived in a world of instability, uncertainty, and chaos, fully aware that the security of the state was always at risk in the designs of disloyal Americans at home and potential foreign enemies abroad. The Framers nonetheless recognized that an even greater danger lay in permitting the 
government to punish individuals as enemies of the state without significant procedural protections. It is this lesson that lies at the heart of Article III's least-known provision, a provision that must inform any serious analysis of the enemy combatant problem. 